\title{
Ruthenium(II) complexes of 1,3-thiazolidine-2-thione: Cytotoxicity against tumor cells and anti-Trypanosoma cruzi activity enhanced upon combination with benznidazole
}

\author{
Rodrigo S. Corrêa a,b,*, Monize M. da Silva a , Angelica E. Graminha a , Cássio S. Meira ${ }^{\mathrm{c}}$, Jamyle A.F. dos Santos ${ }^{\mathrm{c}}$, \\ Diogo R.M. Moreira ${ }^{c}$, Milena B.P. Soares ${ }^{\text {c,d }}$, Gustavo Von Poelhsitz ${ }^{\text {e }}$, Eduardo E. Castellano ${ }^{\text {f }}$, Carlos Bloch Jr ${ }^{g}$, \\ Marcia R. Cominetti ${ }^{\mathrm{h}}$, Alzir A. Batista ${ }^{\mathrm{a}, *}$ \\ a Departamento de Química, Universidade Federal de São Carlos, CP 676, CEP 13565-905 São Carlos, SP, Brazil \\ b Departamento de Química, ICEB, Universidade Federal de Ouro Preto, CEP 35400-000 Ouro Preto, MG, Brazil \\ c Centro de Pesquisas Gonçalo Moniz, Fiocruz, CEP:40296-710 Salvador, BA, Brazil \\ ' Centro de Biotecnologia e Terapia Celular, Hospital São Rafael, Avenida São Rafael, 2152, São Marcos, CEP 41253-190 Salvador, BA, Brazil \\ e Instituto de Química, Universidade Federal de Uberlândia, CP 593, CEP 38400-902 Uberlândia, MG, Brazil \\ ${ }^{\mathrm{f}}$ Instituto de Física, Universidade de São Paulo, CP 369, CEP 13560-970 São Carlos, SP, Brazil \\ g Centro Nacional de Pesquisa de Recursos Genéticos e Biotecnologia, EMBRAPA, Estação Parque Biológico, CEP 70910-900 Brasília, DF, Brazil \\ ${ }^{\text {h }}$ Departamento de Gerontologia, Universidade Federal de São Carlos, CP 676, CEP 13565-905 São Carlos, SP, Brazil
}

\section{A R T I C L E I N F O}

Article history:

Received 2 September 2015

Received in revised form 16 December 2015

Accepted 28 December 2015

Available online 2 January 2016

\section{Keywords:}

$\mathrm{Ru}(\mathrm{II})$ complexes

Cytotoxicity

Trypanosoma cruzi

ctDNA-binding

1,3-Thiazolidine-2-thione

\begin{abstract}
A B S T R A C T
Three new mixed and mononuclear Ru(II) complexes containing 1,3-thiazolidine-2-thione (tzdtH) were synthesized and characterized by spectroscopic analysis, molar conductivity, cyclic voltammetry, high-resolution electrospray ionization mass spectra and X-ray diffraction. The complexes presented unique stereochemistry and the proposed formulae are: $[\mathrm{Ru}(\mathrm{tzdt})(\mathrm{bipy})(\mathrm{dppb})] \mathrm{PF} 6(\mathbf{1})$, cis-[Ru(tzdt $\left.)_{2}\left(\mathrm{PPh}_{3}\right)_{2}\right]$ (2) and trans$\left[\mathrm{Ru}(\mathrm{tzdt})\left(\mathrm{PPh}_{3}\right)_{2}\right.$ (bipy)]PF 6 (3), where dppb = 1,4-bis(diphenylphosphino)butane and bipy $=2,2^{\prime}$-bipyridine. These complexes demonstrated strong cytotoxicity against cancer cell lines when compared to cisplatin. Specifically, complex $\mathbf{2}$ was the most potent cytotoxic agent against MCF-7 breast cells, while complexes $\mathbf{1}$ and $\mathbf{3}$ were more active in DU-145 prostate cells. Binding of complexes to ctDNA was determined by UV-vis titration and viscosity measurements and revealed binding constant $\left(\mathrm{K}_{\mathrm{b}}\right)$ values in range of $1.0-4.9 \times 10^{3} \mathrm{M}^{-1}$, which are characteristic of compounds possessing weak affinity to ctDNA. In addition, these complexes presented antiparasitic activity against Trypanosoma cruzi. Specifically, complex 3 demonstrated strong potency, moderate selectivity index and acted in synergism with the approved antiparasitic drug, benznidazole. Additionally, complex 3 caused parasite cell death through a necrotic process. In conclusion, we demonstrated that Ru(II) complexes have powerful pharmacological activity, while the metal-free tzdtH does not provoke the same outcome.
\end{abstract}

(C) 2015 Elsevier Inc. All rights reserved.

\section{Introduction}

Cancer is considered a group of complex and multifaceted diseases [1]. Carcinogenesis is thought to be initiated by changes to the DNA within cells and also by inhibition of growth suppressors, which, in turn, gives rise to the uncontrolled cell proliferation, invasion of surrounding and distant tissues, and ultimately leads to a risk of aggressive metastasis [2]. Prostate and breast cancers are of high incidence and mortality around the world and the development of new drugs is of interest [3]. Drugs containing transition metals hold a promising possibility for cancer

\footnotetext{
* Corresponding authors.

E-mail addresses: rodrigocorrea@iceb.ufop.br (R.S. Corrêa), daab@ufscar.br (A.A. Batista).
}

treatment. Although cisplatin has been largely employed alone or in drug combinations against prostate and breast cancers, limitations regarding resistance has been observed [4,5]. To overcome cisplatin limitation, Satraplatin, the first orally available Pt drug, is currently undergoing clinical investigation [6]. Ruthenium compounds are promising pharmaceuticals because of many biological features, such as reduced toxicity, suitable biodistribution, and mechanisms of action different than platinum-based compounds [7,8]. In the last years, $\mathrm{Ru}(\mathrm{III})$ complexes have entered clinical trials: NAMI-A [ImH][trans-RuCl$\left.{ }_{4}(\mathrm{DMSO})(\mathrm{Im})\right], \mathrm{KP} 1019$ (indazolium trans-[tetrachloridobis(1H-indazole)ruthenate(III)]) and NKP-1339 [sodium trans-[tetrachloridobis(1H-indazole)ruthenate(III)] [9,10]. The half-sandwich $\eta^{6}$-arene-Ru(II) complexes are a promising class of antitumor compounds with particular emphasis on the $\left[\mathrm{RuCl}_{2}\left(\eta^{6}-\mathrm{p}-\right.\right.$ cymene)(PTA)], PTA = 1,3,5-triaza-7-phosphaadamantane, named as RAPTA-C [11]. This compound is highly active in vivo against metastatic 
cells by inhibiting cathepsin $\mathrm{B}$, a protease related to tumor invasion and metastasis [12,13].

Regarding parasitic infections, American trypanosomiasis (Chagas disease) is an important health problem in Latin America, affecting 814 million people (14,000 deaths per year) with different forms of the pathology $[14,15]$. It is of great concern due to the development of chronic cardiomyopathy and other related health problems [16]. Chemotherapy is only based on nifurtimox and benznidazole ( $\mathrm{Bdz}$ ), drugs that are more than 50 years old and suffer from low efficacy and high levels of toxicity [17]. Since the discovery of an efficient $\mathrm{Ru}(\mathrm{II})$ complex containing clotrimazole against Trypanosoma cruzi, a large number of metal complexes have been evaluated for this purpose [18]. Strategies for the development of new anti-trypanosomal metallodrugs generally involve: coordination of antiparasitic ligands to the metal, and coordination of DNA intercalators to the metal and metal compounds as direct inhibitors of parasite enzymes [19,20].

In view of this, our research group has been studying a number of pharmacological properties for $\mathrm{Ru}(\mathrm{II})$ complexes containing phosphines and diimines ligands as anticancer and anti-infectious agents [21-27]. Remarkable activities were observed for complexes with general formulae $[\mathrm{Ru}(\mathrm{pic})(\mathrm{dppb})(\mathrm{N}-\mathrm{N})] \mathrm{PF}_{6}$, where pic = 2-pyridinecarboxylate; $\mathrm{N}-\mathrm{N}=2,2$-bipyridine or 1,10'-phenanthroline. These complexes displayed strong in vitro activity against Mycobacterium tuberculosis and more importantly, presented activity against multi-resistant strains. In view of these results with bidentate $\mathrm{N}, \mathrm{O}$-ligand (pic), we sought to investigate $\mathrm{Ru}$ complexes containing bidentate $N, S$-ligands. In fact, heterocyclic $N, S$-ligands have been extensively used in the preparation of metal complexes for therapeutic application [27-29]. Among them, an interesting ligand is 1,3-thiazolidine-2-thiol (tzdtH), which has a classical thiol/thione tautomerism as shown in Fig. 1. Crystallographic studies for tzdtH structure indicate that the thione tautomer (form II; Fig. 1) is present in the solid state [30]. However, two tautomeric forms can be found in aqueous and in organic solutions (i.e., 1,4-dioxane, $\mathrm{CCl}_{4}$, benzene, $\mathrm{CHCl}_{3}, \mathrm{CH}_{2} \mathrm{Cl}_{2}, \mathrm{C}_{2} \mathrm{H}_{4} \mathrm{Cl}_{2 \mathrm{~s}}$, $\mathrm{EtOH}, \mathrm{MeOH}, \mathrm{CH}_{3} \mathrm{CN}$, DMF and DMSO) [31,32]. Given this promising outlook and considering the different coordination sites of the tzdtH [33-35], this work aimed to study the reactivity of this ligand with $\mathrm{Ru}(\mathrm{II})$ phosphine precursors. To the best of our knowledge, only three ruthenium organometallic compounds with anionic $\mathrm{tzdt}^{-}$are described in the literature, however no detailed structural as well as pharmacological evaluation were carried out [36,37]. Thus, here three new Ru(II) complexes with the formulae [Ru(tzdt)(bipy)(dppb)]PF6 (1), cis-[Ru(tzdt $\left.)_{2}\left(\mathrm{PPh}_{3}\right)_{2}\right]$ (2) and trans-[Ru(tzdt) $\left.\left(\mathrm{PPh}_{3}\right)_{2}(\mathrm{bipy})\right] \mathrm{PF}_{6}(\mathbf{3})$, were obtained and evaluated as cytotoxic and antiparasitic agents.

\section{Experimental}

\subsection{General}

Reactions and chemicals were handled under Argon atmosphere. Solvents were purified by standard methods. Chemicals used were of reagent grade or comparable purity. $\mathrm{RuCl}_{3} \cdot 3 \mathrm{H}_{2} \mathrm{O}$, dppb, bipy and

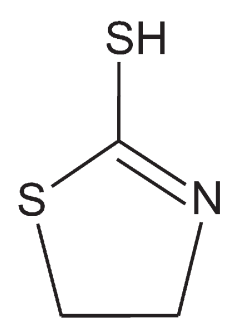

(I)

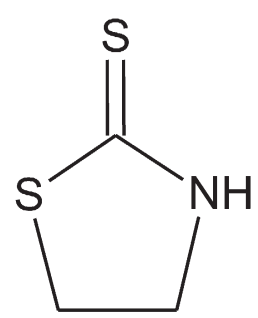

(II)

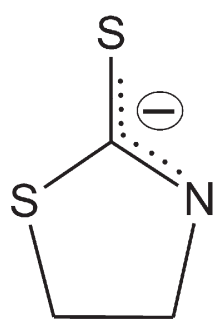

(III)
Fig. 1. The tautomeric (I and II) and anionic (III) structures of the tzdtH ligand.
tzdtH were purchased from Sigma-Aldrich (St. Louis, MO) and used as supplied. The reactants cis-[RuCl$(\mathrm{dppb})$ (bipy)] [38], $\left[\mathrm{RuCl}_{2}\left(\mathrm{PPh}_{3}\right)_{3}\right]$ [39] and cis-[RuCl${ }_{2}\left(\mathrm{PPh}_{3}\right)_{2}$ (bipy)] [40] precursors were prepared according to literature. The IR spectra were recorded on a FT-IR Bomem-Michelson 102 spectrometer in the $4000-250 \mathrm{~cm}^{-1}$ region, using CsI pellets. Conductivity values were obtained at room temperature using $10^{-3} \mathrm{M}$ solutions of the complexes in $\mathrm{CH}_{2} \mathrm{Cl}_{2}$ by using a Meter Lab CDM2300 instrument. ${ }^{1} \mathrm{H},{ }^{31} \mathrm{P}\left\{{ }^{1} \mathrm{H}\right\}$ and ${ }^{13} \mathrm{C}\left\{{ }^{1} \mathrm{H}\right\}$ NMR were recorded on a Bruker DRX $400 \mathrm{MHz}$ using tetramethylsilane as reference and solvent $\mathrm{CDCl}_{3}$ to the complexes $\mathbf{1}$ and $\mathbf{2}$ and acetone- $d_{6}$ to complex 3. The ${ }^{31} \mathrm{P}\left\{{ }^{1} \mathrm{H}\right\}$ chemical shifts are reported in relation to $\mathrm{H}_{3} \mathrm{PO}_{4}, 85 \%$. The UV-vis spectra of the complexes, (concentration c.a. $10^{-4} \mathrm{M}$ ), were recorded in $\mathrm{CH}_{2} \mathrm{Cl}_{2}$ on a Hewlett Packard diode array-8452 A. Cyclic voltammetry experiments were performed in an electrochemical analyzer BAS, model 100B and carried out at room temperature. Typical conditions were: $\mathrm{CH}_{2} \mathrm{Cl}_{2}$ containing $0.10 \mathrm{M} \mathrm{Bu}_{4} \mathrm{NClO}_{4}$ (TBAP) as supporting electrolyte, and using a one-compartment cell, both working and auxiliary electrodes were stationary Pt foils, and the reference electrode was $\mathrm{Ag} / \mathrm{AgCl}, 0.10 \mathrm{M}$ TBAP in $\mathrm{CH}_{2} \mathrm{Cl}_{2}$. Ferrocene $(\mathrm{Fc})$ was employed for calibrating the electrochemical system and the redox potential. Under these conditions, $\left(\mathrm{Fc}^{+} / \mathrm{Fc}\right)$ couple presented $430 \mathrm{mV}$. High resolution mass spectra of complexes were obtained by direct infusion in a MicroTof-Q II Bruker Daltonics Mass Spectrometer (Le) in the positive ion mode, employing methanol as solvent (LC/MS grade from Honeywell/B\&J Brand). Elemental analyses were carried out in the Microanalytical Laboratory of Federal University of São Carlos, with an EA 1108 FISONS Instruments CHNS microanalyzer.

\subsection{Synthesis and characterization}

\subsection{1. $[R u(t z d t)($ bipy) $(d p p b)] P F 6$ (1)}

In a Schlenk flask, $16 \mathrm{mg}(0.14 \mathrm{mmol})$ of tzdtH was dissolved in $10 \mathrm{~mL}$ of a $\mathrm{CH}_{2} \mathrm{Cl}_{2}$ solution containing $20 \mu \mathrm{L}$ of triethylamine. After, $100 \mathrm{mg}(0.12 \mathrm{mmol})$ of $c i s-\left[\mathrm{RuCl}_{2}(\mathrm{dppb})\right.$ (bipy)] reactant was added and maintained under stirring at room temperature for $3 \mathrm{~h}$. Then, $30 \mathrm{mg}(0.18 \mathrm{mmol})$ of $\mathrm{NH}_{4} \mathrm{PF}_{6}$ was added and the volume concentrated under reduced pressure to ca. $2 \mathrm{~mL}$. Orange crystals were separated by filtration, washed with dry diethyl ether and dried under vacuum to yield $94 \mathrm{mg}$ (83\%). Anal. Calc. for $\left[\mathrm{RuC}_{41} \mathrm{H}_{40} \mathrm{~N}_{3} \mathrm{P}_{2} \mathrm{~S}_{2}\right] \mathrm{PF}_{6}$ : exp. (calc) 51.90 (52.01); H, 4.21 (4.26); N, 4.28 (4.44); S, 6.55 (6.77) \%. Molar conductance $\left(\mathrm{S} \mathrm{cm}^{2} \mathrm{~mol}^{-1}, \mathrm{CH}_{2} \mathrm{Cl}_{2}\right)$ 46.5. IR $\left(\mathrm{cm}^{-1}\right)$ : (vC-H) 3076, 3053, 2949, 2924; $\left(v_{C_{2}}\right)$ 2854, 2679; (vCN) 1535, 1433; $\left(v C_{(\text {ring })}+v C_{(\mathrm{dppb})}\right) 1483,1309 ;(v C-S) 1159 ;(v C-P) 1094 ;\left(v_{\text {ring }}\right)$ 1043, 997; (vP-F) 843; ( $\gamma C S)$ 764; ( $\gamma_{\text {ring }}$ ) 698; (vRu-P) 517, 507; (vRu-S) 492; (vRu-N) 426. ${ }^{31} \mathrm{P}\left\{{ }^{1} \mathrm{H}\right\}$ NMR $\left(162 \mathrm{MHz}, \mathrm{CDCl}_{3}, 298 \mathrm{~K}\right): \delta$ (ppm) (d, 43.2 and $\left.44.6,{ }^{2} \mathrm{~J}=35.1 \mathrm{~Hz}\right) ;{ }^{1} \mathrm{H}$ NMR $\left(400 \mathrm{MHz}, \mathrm{CDCl}_{3}\right.$, $298 \mathrm{~K}): \delta$ (ppm): 8.96 (1H, d, bipy); 8.74 (1H, br. s, bipy); 8.09 (1H, m, bipy); 8.03 (1H, m, bipy); 7.85 (1H, m, bipy); 7.73 (1H, m, bipy); 7.45 (2H, t, $\mathrm{H}_{\mathrm{p}}$ of dppb); 7.41-6.93 (16H, m, $\mathrm{H}_{\mathrm{o}}$ and $\mathrm{H}_{\mathrm{m}}$ of dppb); $6.89(2 \mathrm{H}$, $\mathrm{t}$, bipy); $6.38\left(2 \mathrm{H}, \mathrm{t}, \mathrm{H}_{\mathrm{p}}\right.$ of $\left.\mathrm{dppb}\right) ; 3.40-2.30\left(4 \mathrm{H}, \mathrm{m}, \mathrm{CH}_{2}\right.$ of $\left.\mathrm{tzdt}\right)$; 2.30-1.03 (8H, m, $\mathrm{CH}_{2}$ of dppb). ${ }^{13} \mathrm{C}\left\{{ }^{1} \mathrm{H}\right\}$ NMR (125.74 MHz, $\mathrm{CDCl}_{3}$, $298 \mathrm{~K}): \delta$ (ppm) 183.75 (CS); 158.09-151.45 (C-Bipy), 139.93-121.92 (C-dppb and C-Bipy); 55.26 (1C, $\mathrm{CH}_{2}-\mathrm{N}$ of tzdt) and 32.03 (1C, $\mathrm{CH}_{2}-\mathrm{S}$ of tzdt); $31.75-21.29$ (C- $\mathrm{CH}_{2}$ of dppb). UV-vis $\left(\mathrm{CH}_{2} \mathrm{Cl}_{2}\right.$, $\left.1.6 \times 10^{-4} \mathrm{M}\right): \lambda / \mathrm{nm}\left(\varepsilon / \mathrm{M}^{-1} \mathrm{~cm}^{-1}\right) 296(15,970), 420(2850)$.

\subsection{2. cis- $\left[R u(t z d t)_{2}\left(\mathrm{PPh}_{3}\right)_{2}\right](\mathbf{2})$}

In the Schlenk flask, $20 \mathrm{mg}(0.17 \mathrm{mmol})$ of tzdtH was dissolved in $60 \mathrm{~mL}$ of ethanol. To this, $60 \mathrm{~mL}$ of $\mathrm{CH}_{2} \mathrm{Cl}_{2}$ containing $30 \mu \mathrm{L}$ of $\mathrm{Et}_{3} \mathrm{~N}$ followed by $70 \mathrm{mg}$ of $\left[\mathrm{RuCl}_{2}\left(\mathrm{PPh}_{3}\right)_{3}\right]$ reactant were added. After stirring for 30 min, under room temperature, color mixture changed from a brownish to a yellowish suspension. Solvent was removed under reduced pressure and the yellowish solid was filtered and washed with ethanol and diethyl ether and then dried under vacuum to yield $50 \mathrm{mg}$ (79\%). Anal. Calc. for $\left[\mathrm{RuC}_{42} \mathrm{H}_{38} \mathrm{~N}_{2} \mathrm{~S}_{4} \mathrm{P}_{2}\right] .1 / 2 \mathrm{H}_{2} \mathrm{O}$ : exp. (calc) 57.76 (57.91); $\mathrm{H}, 4.22$ (4.51); N, 3.33 (3.22); S, 15.17 (14.73) \%. Molar conductance ( $\mathrm{S} \mathrm{cm}^{2} \mathrm{~mol}^{-1}$, 
$\left.\mathrm{CH}_{2} \mathrm{Cl}_{2}\right)$ 1.8. IR $\left(\mathrm{cm}^{-1}\right)$ (vC-H) 3072, 3049, 2947, 2928; (vCH $)$ 2849; (vCN) 1527; 1508; ( $\left.\nu \mathrm{CC}_{\text {(ring) }}+\nu \mathrm{CC}_{(\mathrm{dppb})}\right)$ 1479, 1385; (vC-S) 1188; (vC-P) 1088; ( $\left.v_{\text {ring }}\right) 1045$, 993; ( $\left.\gamma C S\right)$ 750; $\left(\gamma_{\text {ring }}\right)$ 696; (vRu-P) 520; (vRu-S) 497; (vRu-N) 435. ${ }^{31} \mathrm{P}\left\{{ }^{1} \mathrm{H}\right\} \mathrm{NMR}\left(162 \mathrm{MHz}, \mathrm{CDCl}_{3}, 298 \mathrm{~K}\right): \delta$ (ppm) $54.2(\mathrm{~s}) ;{ }^{1} \mathrm{H}$ NMR $\left(400 \mathrm{MHz}, \mathrm{CDCl}_{3}, 298 \mathrm{~K}\right): \delta(\mathrm{ppm}): 7.32(12 \mathrm{H}$, $\mathrm{m}, \mathrm{H}_{\mathrm{o}}$ of $\left.\mathrm{PPh}_{3}\right) ; 7.23\left(6 \mathrm{H}, \mathrm{t}, \mathrm{H}_{\mathrm{p}}\right.$ of $\left.\mathrm{PPh}_{3}\right) ; 7.10\left(12 \mathrm{H}, \mathrm{t}, \mathrm{H}_{\mathrm{m}}\right.$ of $\left.\mathrm{PPh}_{3}\right) ; 3.27$ (2H, ddd, $\mathrm{CH}_{2}$ of tzdt); 3.20 (2H, dd, $\mathrm{CH}_{2}$ of tzdt); 2.94 (2H, ddd, $\mathrm{CH}_{2}$ of tzdt); 2.65 (2H, dd, $\mathrm{CH}_{2}$ of tzdt). ${ }^{13} \mathrm{C}\left\{{ }^{1} \mathrm{H}\right\}$ NMR (125.74 $\mathrm{MHz}, \mathrm{CDCl}_{3}$, $298 \mathrm{~K}): \delta(\mathrm{ppm}) 181.88$ (CS); 137.33-127.09 (36C, C-PPh 3 ); 56.49 (2C, $\mathrm{CH}_{2}-\mathrm{N}$ of tzdt) and $31.72\left(2 \mathrm{C}, \mathrm{CH}_{2}-\mathrm{S}\right.$ of tzdt). UV-vis $\left(\mathrm{CH}_{2} \mathrm{Cl}_{2}\right.$, $\left.4 \times 10^{-5} \mathrm{M}\right): \lambda / \mathrm{nm}\left(\varepsilon / \mathrm{M}^{-1} \mathrm{~cm}^{-1}\right) 310$ (1993).

\subsection{3. trans- $\left[R u(T z d t)\left(P^{2} h_{3}\right)_{2}(\right.$ Bipy $\left.)\right] P F_{6}(3)$}

In the Schlenk flask, $33 \mathrm{mg}(0.137 \mathrm{mmol})$ of tzdtH was dissolved in a mixture of $\mathrm{CH}_{2} \mathrm{Cl}_{2}: \mathrm{MeOH}(80: 20)$ containing $20 \mu \mathrm{Et}_{3} \mathrm{~N}$. Then, $100 \mathrm{mg}$ ( $0.114 \mathrm{mmol})$ of cis- $\left[\mathrm{RuCl}_{2}\left(\mathrm{PPh}_{3}\right)_{2}\right.$ (bipy)] reactant was added and the mixture was stirred under reflux temperature for $24 \mathrm{~h}$. After this, the resulting orange solution was concentrated under reduced pressure to $2 \mathrm{~mL}$ and $10 \mathrm{~mL}$ of water was added. The resulting orange solid was filtered, washed with warmed water, diethyl ether and then dried under vacuum to yield $113 \mathrm{mg}$ (92\%). Anal. Calc. for $\left[\mathrm{RuC}_{49} \mathrm{H}_{42} \mathrm{~N}_{3} \mathrm{~S}_{2} \mathrm{P}_{2}\right] \mathrm{PF}_{6} \cdot 2 \mathrm{H}_{2} \mathrm{O}$ : exp. (calc) 54.69 (54.44); H, 4.12 (4.29); $\mathrm{N}, 3.97$ (3.89); S, 6.23 (5.93) \%. Molar conductance ( $\mathrm{S} \mathrm{cm}^{2} \mathrm{~mol}^{-1}$, $\left.\mathrm{CH}_{2} \mathrm{Cl}_{2}\right)$ 50.2. IR $\left(\mathrm{cm}^{-1}\right)$ : (vC-H) 3076; 3055; 2951; 2924; $\left(\mathrm{vCH}_{2}\right)$ 2852; (vCN) 1528, 1433; ( $\left.\nu \mathrm{CC}_{(\text {ring })}+\nu \mathrm{CC}_{(\mathrm{dppb})}\right) 1384 ; 1307 ;(v C-\mathrm{S})$ 1159; (vC-P) 1090; ( $\left.\nu_{\text {ring }}\right) 1051,999 ;(v P-F) 840 ;(\gamma C S) 762 ;\left(\gamma_{\text {ring }}\right)$ 698; (vRu-P) 519; (vRu-S) 492; (vRu-N) 438. ${ }^{31} \mathrm{P}\left\{{ }^{1} \mathrm{H}\right\} \quad \mathrm{NMR}$ $\left(162 \mathrm{MHz}, \mathrm{CDCl}_{3}, 298 \mathrm{~K}\right): \delta$ (ppm) $33.3(\mathrm{~s}) ;{ }^{1} \mathrm{H} \mathrm{NMR}\left(400 \mathrm{MHz}, \mathrm{CDCl}_{3}\right.$, $298 \mathrm{~K}): \delta(\mathrm{ppm}): 9.75$ (1H, d, bipy); 9.02 (1H, d, bipy); $7.71(2 \mathrm{H}, \mathrm{m}$, bipy); 7.65 (2H, m, bipy); $7.57\left(1 \mathrm{H}, \mathrm{m}\right.$, bipy); $7.35\left(6 \mathrm{H}, \mathrm{m}, \mathrm{H}_{\mathrm{p}}\right.$ of $\left.\mathrm{PPh}_{3}\right) ; 7.28\left(12 \mathrm{H}, \mathrm{m}, \mathrm{H}_{\mathrm{o}}\right.$ of $\left.\mathrm{PPh}_{3}\right) ; 7.20\left(12 \mathrm{H}, \mathrm{m}, \mathrm{H}_{\mathrm{m}}\right.$ of $\left.\mathrm{PPh}_{3}\right) ; 7.11(1 \mathrm{H}$, m, bipy); 3.37 (2H, t, $\mathrm{CH}_{2}$ of tzdt); $2.57\left(2 \mathrm{H}, \mathrm{t}, \mathrm{CH}_{2}\right.$ of tzdt $) .{ }^{13} \mathrm{C}\left\{{ }^{1} \mathrm{H}\right\}$ NMR (125.74 MHz, $\left.\mathrm{CDCl}_{3}, 298 \mathrm{~K}\right): \delta(\mathrm{ppm}) 182.52$ (CS); 158.68-153.62 (C-Bipy), 136.58-123.77 (C-PPh 3 and C-Bipy); 57.41 (1C, $\mathrm{CH}_{2}-\mathrm{N}$, tzdt), $31.77\left(1 \mathrm{C}, \mathrm{CH}_{2}-\mathrm{S}\right.$, tzdt). UV-vis $\left(\mathrm{CH}_{2} \mathrm{Cl}_{2}\right.$, $\left.8 \times 10^{-5} \mathrm{M}\right): \lambda / \mathrm{nm}\left(\varepsilon / \mathrm{M}^{-1} \mathrm{~cm}^{-1}\right) 280$ (26266), 302 (17927), 348 (5488), 444 (3434).

\subsection{X-ray diffraction}

Single crystals of the complexes were grown from diethyl ether diffusion into a dichloromethane solution of complex at room temperature (293 K). X-ray diffraction experiments were carried out at room temperature using a suitable crystal mounted on glass fiber, and positioned on the goniometer head. Intensity data were measured on an EnrafNonius Kappa-CCD diffractometer with graphite monochromated MoK $\alpha$ radiation $(\lambda=0.71073 \AA$ ). The cell refinements were performed using the software Collect [41] and Scalepack [42], and the final cell parameters were obtained on all reflections. The structures were solved by direct method using SHELXS-97 and refined using the software SHELXL-97. In all complexes' structures, the Gaussian method was used for the absorption corrections [43]. Non-hydrogen atoms of the complexes were unambiguously located, and a full-matrix, leastsquares refinement of these atoms with anisotropic thermal parameters was carried out. In all ligands of the complexes, aromatic $\mathrm{C}-\mathrm{H}$ hydrogen atoms were positioned stereochemically and were refined with fixed individual displacement parameters $\left[\mathrm{U}_{\mathrm{iso}}(\mathrm{H})=1.2 \mathrm{U}_{\mathrm{eq}}\left(\mathrm{Csp}^{2}\right)\right]$ using a riding model with aromatic, $\mathrm{C}-\mathrm{H}$ bond lengths which were fixed at $0.93 \AA$ A. Methylene groups of tzdt ligand were also set as isotropic with a thermal parameter $20 \%$ greater than the equivalent isotropic displacement parameter of the atom to which each one was bonded and $\mathrm{C}-\mathrm{H}$ bond lengths were fixed at $0.97 \AA$. Tables were generated by WinGX and the structure representations by MERCURY. The CrystalExplorer 2.1 program was used to generate the Hirshfeld surfaces and the fingerprint plot. The Hirshfeld surfaces were employed to define the intermolecular environment of molecules within the crystal of each complex
[44-46]. The fingerprint plot or 2D-fingerprint graphics is constructed by the plot of $d e$ versus $d i$ ( $d e=$ external distance is defined as the distance between the calculated Hirshfeld surface and the nearest atom of an adjacent molecule; $d i=$ internal distance is distance between the nearest nucleus internal and the calculated Hirshfeld surface). Relationships between crystal packing pattern and molecular geometry were determined by analyzing parameters present in Hirshfeld fingerprint plots. The 2D-fingerprint also provides the percentage of each intermolecular contact occurring in the complex structure. Crystallography data were registered in the Cambridge Crystallographic Data Centre (CCDC), with the respective deposit numbers: 1037025 (1), 1037026 (2) and 1037027 (3).

\subsection{DNA binding}

\subsubsection{Spectroscopic titration}

A solution of calf thymus DNA (ctDNA, Sigma-Aldrich) was prepared in Tris- $\mathrm{HCl}$ buffer ( $5 \mathrm{mM}$ Tris- $\mathrm{HCl}, \mathrm{pH}$ 7.2). A solution of ctDNA in the buffer gave a ratio of UV absorbance at 260 and $280 \mathrm{~nm}$ of about 1.8:1, indicating that the solution is protein-free. The concentration of ctDNA was measured from its absorption intensity at $260 \mathrm{~nm}$ using the molar absorption coefficient value of $6600 \mathrm{M}^{-1} \mathrm{~cm}^{-1}$ [47]. Solutions of $\mathrm{Ru}$ (II) complexes used in the experiments were prepared in Tris- $\mathrm{HCl}$ buffer containing 5\% DMSO. To the ctDNA titration experiments, different concentrations of the ctDNA were used (ranging $3.8 \times 10^{-5}$ to $7.6 \times 10^{-4} \mathrm{M}$ ), while the concentration of ruthenium complexes were maintained at $1.6 \times 10^{-4}, 4.4 \times 10^{-5}$ and $8.6 \times 10^{-5} \mathrm{M}$ for $\mathbf{1 , 2}$ and $\mathbf{3}$, respectively. Sample correction was done for the absorbance of DNA and the spectra were recorded after solution equilibration for $2 \mathrm{~min}$. It is worth mentioning that complex $\mathbf{2}$ and $\mathbf{3}$ structures change after incubating in the buffered medium, such as observed in the ${ }^{31} \mathrm{P}$ NMR spectrum of complexes $\mathbf{2}$ and $\mathbf{3}$ (see the Supplementary material). These chances can be attributed to exchange of the monodentate $\mathrm{PPh}_{3}$ ligand. As a result, the signal of $\mathrm{PPh}_{3}$ free is observed at around $-6.3 \mathrm{ppm}$. The intrinsic equilibrium binding constant $\left(\mathrm{K}_{\mathrm{b}}\right)$ of the complexes to ctDNA was obtained using the McGhee-von Hippel (MvH) method [48] by using the expression of Wolfe and co-workers [49]:

$[\mathrm{ctDNA}] /\left(\varepsilon_{\mathrm{a}}-\varepsilon_{\mathrm{f}}\right)=[\mathrm{ctDNA}] /\left(\varepsilon_{\mathrm{b}}-\varepsilon_{\mathrm{f}}\right)+1 / \mathrm{K}_{\mathrm{b}}\left(\varepsilon_{\mathrm{b}}-\varepsilon_{\mathrm{f}}\right)$

in which [ctDNA] is the concentration of ctDNA in base pairs, $\varepsilon_{\mathrm{a}}$ is the ratio of the absorbance/[Ru(II) complex], $\varepsilon_{\mathrm{f}}$ is the extinction coefficient of the free $\mathrm{Ru}(\mathrm{II})$ complex, and $\varepsilon_{\mathrm{b}}$ is the extinction coefficient of the complex in the fully bound form. The ratio of the slope to the intercept

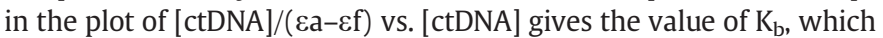
was calculated from the metal to ligand charge transfer (MLCT) absorption band $\left(\lambda_{\max }\right)$. Changes in the absorption intensity increasing concentration of ctDNA was monitored and analyzed by regression analysis. The nonlinear least-squares analysis was calculated by using OriginLab.

\subsubsection{Viscosity measurements}

Viscometric titrations of 1-3 were performed using an Ostwald viscometer in a constant temperature $\left(37^{\circ} \mathrm{C}\right)$. The concentration of ctDNA was $4.2 \times 10^{-3} \mu \mathrm{M}$, and the flow times were measured with an automated timer. Each sample was measured 5 times and an average flow time was calculated. Data were presented as $\left(\eta / \eta_{\mathrm{o}}\right)^{1 / 3}$ versus [complex]/[ctDNA], where $\eta$ is the viscosity of ctDNA in the presence of the complex and $\eta_{\mathrm{o}}$ is that of ctDNA alone. Relative viscosity for ctDNA in either the presence or absence of complex was calculated from the relation: $\eta=\left(t-t_{0}\right) /\left(t_{0}\right)$, where $t$ is the observed flow time of the ctDNA containing solution and $t_{o}$ is the flow time of buffer alone. 


\subsection{Cytotoxicity against cancer cells}

Human tumor breast cell line MCF-7 (ATCC No. HTB-22) and human prostate tumor cell line DU-145 (ATCC: HTB-81) were cultured in RPMI1640 medium (Sigma-Aldrich) supplemented with $20 \%$ fetal bovine serum (FBS; Cultilab, Campinas, Brazil) at $37{ }^{\circ} \mathrm{C}$ in $5 \% \mathrm{CO}_{2}$. Aliquots of $200 \mu \mathrm{L}$ containing $1 \times 10^{4}$ cells were seeded in 96-well microplates and incubated for $12 \mathrm{~h}$. Drugs were dissolved in sterile DMSO (stock solution with maximum concentration of $20 \mathrm{mM}$ ) and diluted in RPMI1640 medium from 0.05 to $200 \mu \mathrm{M}$ (final concentration of $1 \%$ DMSO per well). Negative control (without drug) and positive control (cisplatin) were included in the plate and then incubated for $48 \mathrm{~h}$ at $37^{\circ} \mathrm{C}$ in $5 \%$ $\mathrm{CO}_{2}$. After incubation, cells were washed twice with phosphate buffer saline, $50 \mu \mathrm{L}$ of MTT (MTT, Life, Carlsbad, USA) at $0.5 \mathrm{mg} \mathrm{mL}^{-1}$ was added and incubated for $4 \mathrm{~h}$, followed by adding $100 \mu \mathrm{L}$ of isopropanol. Colorimetric reading was performed in a microplate reader at $595 \mathrm{~nm}$. Cell viability was measured in comparison to the negative control (cells receiving only DMSO). Inhibitory concentration to 50\% ( $\mathrm{IC}_{50}$ ) was determined by using non-linear regression. Three independent experiments were performed.

\subsection{Host cell toxicity}

J774 macrophages were seeded on 96-well plates at a cell number of $5 \times 10^{4}$ cells $\mathrm{mL}^{-1}$ in $200 \mu \mathrm{L}$ of RPMI medium (Sigma-Aldrich) supplemented with $10 \%$ of FBS (Life, Carlsbad, USA) and $50 \mu \mathrm{g} \mathrm{mL}-1$ of gentamycin (Life) and incubated for $24 \mathrm{~h}$ at $37{ }^{\circ} \mathrm{C}$ and $5 \% \mathrm{CO}_{2}$. After that time each compound was added at six concentrations $(0.04$ to $10 \mu \mathrm{M})$ in triplicate and incubated for $72 \mathrm{~h}$. Cell viability was determined by AlamarBlue assay (Life) according to the manufacturer's instructions. Colorimetric readings were performed after $6 \mathrm{~h}$ at 570 and $600 \mathrm{~nm}$. Cytotoxic concentration to $50 \%\left(\mathrm{CC}_{50}\right)$ was calculated using data-points gathered from three independent experiments. Gentian violet (Synth, São Paulo, Brazil) was used as positive control.

\subsection{Antiparasitic activity}

\subsubsection{Cytotoxicity for trypomastigotes}

Trypomastigotes collected from the supernatants of previously infected LLC-MK2 cells were dispensed into 96-well plates at a cell number of $2 \times 10^{6}$ cells $\mathrm{mL}^{-1}$ in $200 \mu \mathrm{L}$ of RPMI medium. Compounds were tested at concentration range of 0.02 to $10 \mu \mathrm{M}$, in triplicate. The plate was incubated for $24 \mathrm{~h}$ at $37{ }^{\circ} \mathrm{C}$ and $5 \% \mathrm{CO}_{2}$. Aliquots from each well were collected and the number of viable parasites was assessed in a Neubauer chamber and compared to untreated parasite culture. This experiment was performed three times. Benznidazole (LAFEPE, Recife, Brazil) was used as the positive control. Cytotoxic concentration to $50 \%\left(\mathrm{CC}_{50}\right)$ was calculated using data-points gathered from three independent experiments.

\subsubsection{Inhibition of parasite infection}

Peritoneal macrophages $\left(2 \times 10^{5}\right.$ cells $\left.\mathrm{mL}^{-1}\right)$ obtained from BALB/c mice were seeded in a 24 well-plate with rounded coverslips on the bottom in RPMI supplemented with 10\% FBS and incubated for $24 \mathrm{~h}$. Cells were then infected with trypomastigotes (10:1) for 2 h. Free trypomastigotes were removed by successive washes using saline solution and the cells were incubated for $24 \mathrm{~h}$ for internalization and differentiation of trypomastigotes into amastigotes. Following this, cultures were incubated in complete medium alone or with compounds for $72 \mathrm{~h}$. Cells were fixed in absolute alcohol and the percentage of infected macrophages and the number of amastigotes/100 macrophages was determined by manual counting after hematoxylin and eosin staining using an optical microscope (Olympus, Tokyo, Japan). The percentage of infected macrophages and the number of amastigotes per 100 macrophages was determined by counting 100 cells per slide.
The one-way ANOVA and Bonferroni for multiple comparisons were used to determine the statistical significance of the group comparisons. Benznidazole was used as the positive control.

\subsection{Propidium iodide and annexin $V$ staining}

Trypomastigotes $\left(1 \times 10^{7}\right)$ were incubated for $24 \mathrm{~h}$ at $37^{\circ} \mathrm{C}$ in the absence or presence of $\mathrm{Ru}(\mathrm{II})$ complex $3(0.01,0.015$ or $0.02 \mu \mathrm{M})$. After incubation, the parasites were labeled for propidium iodide (PI) and annexin $\mathrm{V}$ using the annexin V-FITC apoptosis detection kit (Sigma-Aldrich), according to the manufacturer's instructions. Acquisition and analyses was performed using a FACS Calibur flow cytometer (Becton Dickinson, CA, USA), with FlowJo software (Tree Star, CA, USA). A total of 30,000 events were acquired in the region previously established as trypomastigote forms of $T$. cruzi. Two independent experiments were performed.

\section{Results}

\subsection{Synthesis, infrared spectroscopy and mass spectrometry}

The chemical reactivity of tzdtH in triethylamine was studied under the presence of metal complexes cis-[ $\mathrm{RuCl}_{2}(\mathrm{dppb})$ (bipy)], $\left[\mathrm{RuCl}_{2}\left(\mathrm{PPh}_{3}\right)_{3}\right]$ and cis- $\left[\mathrm{RuCl}_{2}\left(\mathrm{PPh}_{3}\right)_{2}\right.$ (bipy)]. This led to the formation of complexes with formulae $\left[\mathrm{Ru}(\mathrm{tzdt})(\mathrm{bipy})\left(\mathrm{dppb}_{\mathrm{d}}\right] \mathrm{PF}_{6}(\mathbf{1})\right.$, cis$\left[\mathrm{Ru}(\mathrm{tzdt})_{2}\left(\mathrm{PPh}_{3}\right)_{2}\right](\mathbf{2})$ and trans-[Ru(tzdt) $\left.\left(\mathrm{PPh}_{3}\right)_{2}(\mathrm{bipy})\right] \mathrm{PF}_{6}$ (3) containing the monoanionic $\mathrm{tzdt}^{-}$as chelated ligand as shown in Scheme 1. Each synthetic procedure was straightforward, provided good yields and analytically pure complexes as determined by elemental analyses.

Infrared spectra of complexes 1-3 confirmed the presence of the $\mathrm{tzdt}^{-}$ligand coordinated to the metal center. High energy region of each spectrum exhibited bands at 2854-2849 $\mathrm{cm}^{-1}$, which were assigned to the $v \mathrm{CH}_{2}$ stretching vibration of tdzt ligand. The $v \mathrm{~N}-\mathrm{H}$ stretching vibration at $3138 \mathrm{~cm}^{-1}$ in the spectrum of metal-free tzdtH was absent in the spectra of the ruthenium complexes, suggesting that ligand is coordinated into its deprotonated form. Strong bands found in the region of $1535-1300 \mathrm{~cm}^{-1}$ are characteristic of $v C N$ and $v C C$ stretching vibrations of the $\mathrm{tdzt}^{-}, \mathrm{dppb}$ and bipy ligands. In the complexes, the bands related to $\nu \mathrm{C} \cdots \mathrm{S}$ and $\delta \mathrm{C} \cdots \mathrm{S}$ absorptions of $\mathrm{tdzt}^{-}$occur in the regions around $1188-1159$ and $764-750 \mathrm{~cm}^{-1}$, respectively.

Regarding ESI-MS(+) spectra, complex 1 presented the most intense molecular peak at $802.1179 \mathrm{Da}$, while its predicted monoisotopic mass is $802.1186 \mathrm{Da}$. For complexes 2 and 3, $\mathrm{M}^{+}$peaks occurred at 862.0428 and $900.1345 \mathrm{Da}$, respectively. In both complexes 2 and 3, peaks corresponding to $\left[\mathrm{M}-\mathrm{PPh}_{3}\right]^{+}$were observed.

\subsection{Electrochemical study}

The redox behavior of metal complexes was investigated by cyclic voltammetry (Fig. 2). Complexes 1-3 revealed one-electron waves for $\mathrm{Ru}(\mathrm{II}) / \mathrm{Ru}$ (III) redox process with quasi-reversible behavior at +1150 , +690 and $+926 \mathrm{mV}$. These values highlight the different stereochemistry around the $\mathrm{Ru}(\mathrm{II})$ center. Complex $\mathbf{2}$ exhibited redox process in lower potential than complexes $\mathbf{1}$ and $\mathbf{3}$. This can be explained because of two molecules of $\mathrm{tzdt}^{-}$and the absence of bipy, which is a wellknown $\pi$-electron acceptor ligand. In fact, the bipy-containing complexes $\mathbf{1}$ and $\mathbf{3}$ presented $\mathrm{Ru}(\mathrm{II}) / \mathrm{Ru}(\mathrm{III})$ oxidation peaks around $1000 \mathrm{mV}$, which are similar values to $\mathrm{Ru}(\mathrm{II})$ complexes described in the literature [25,26]. Despite complexes $\mathbf{1}$ and $\mathbf{3}$ presenting the same ligands, $\mathbf{3}$ has a redox potential much lower than $\mathbf{1}$. This may be explained by the competition for electron density around the metal between the phosphorus atoms in trans position observed in complex 3 [27].

The half-wave potential ( $\left.\mathrm{E}^{1} \mathrm{2} / 2\right)$ values for these complexes were more anodic than the starting reactants by approximately $0.60 \mathrm{~V}$ (Table 1 ). 


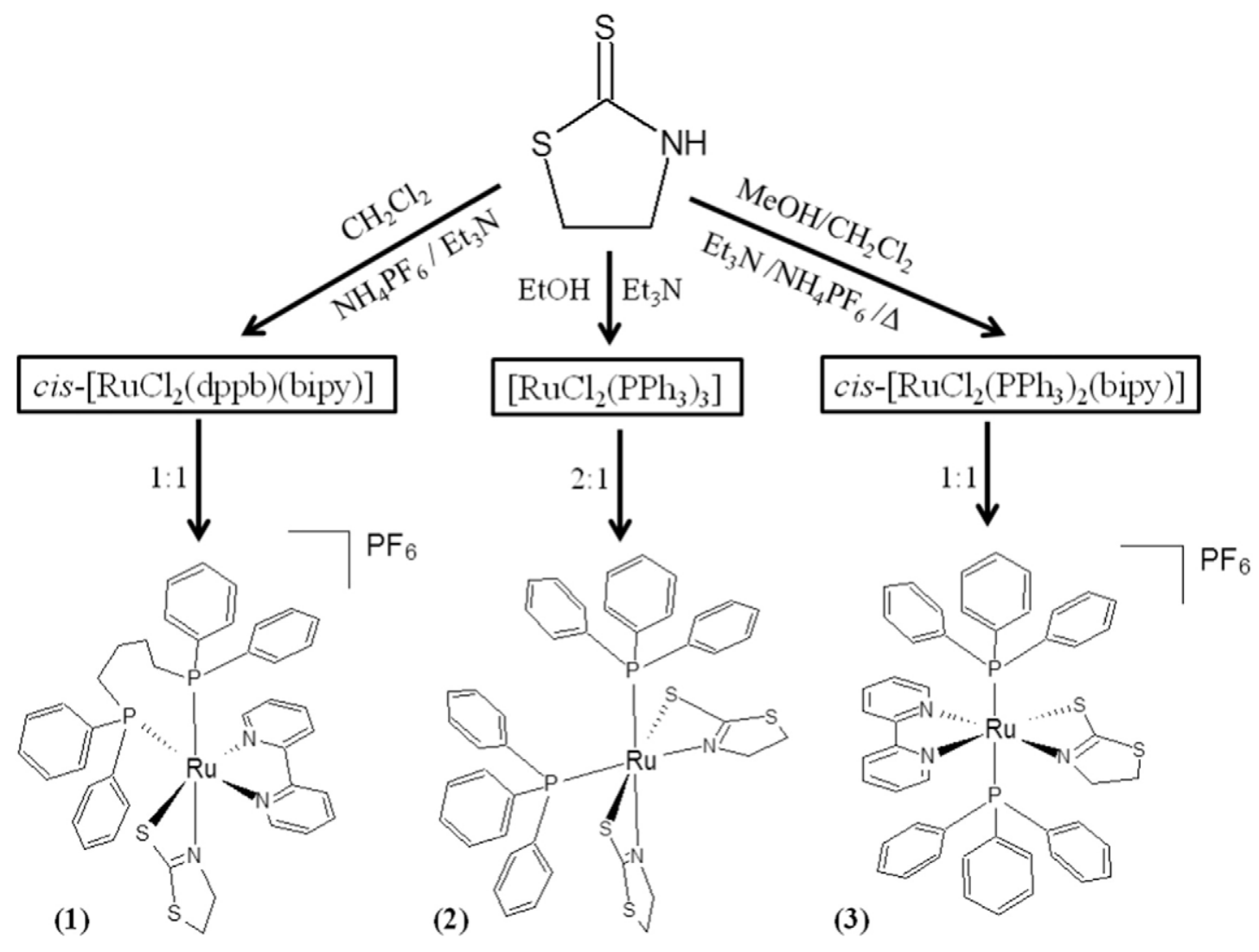

Scheme 1. Routes used to prepare $\mathrm{Ru}(\mathrm{II}) / \mathrm{tzdt}^{-}$complexes.

This indicates that ruthenium is more easily oxidized in metal precursors than complexes (1-3), therefore complexes (1-3) are more stable than their starting reactants. This stabilization is possible due to the replacement of two $\sigma$ and $\pi$ donor chlorides by a negative and monocharged chelating $\mathrm{tzdt}^{-}$, which contains an acceptor group.

\subsection{NMR spectroscopy}

Resonance for complexes $\mathbf{1}$ and $\mathbf{2}$ was carried out in $\mathrm{CDCl}_{3}$, while acetone- $d_{6}$ was used in complex 3 . In the ${ }^{31} \mathrm{P}\left\{{ }^{1} \mathrm{H}\right\}$ NMR spectrum of complex 1, a typical AB spin system was observed with chemical shifts at $43.2(\mathrm{~d})$ and $44.5(\mathrm{~d}) \mathrm{ppm}$, indicating the magnetic nonequivalence

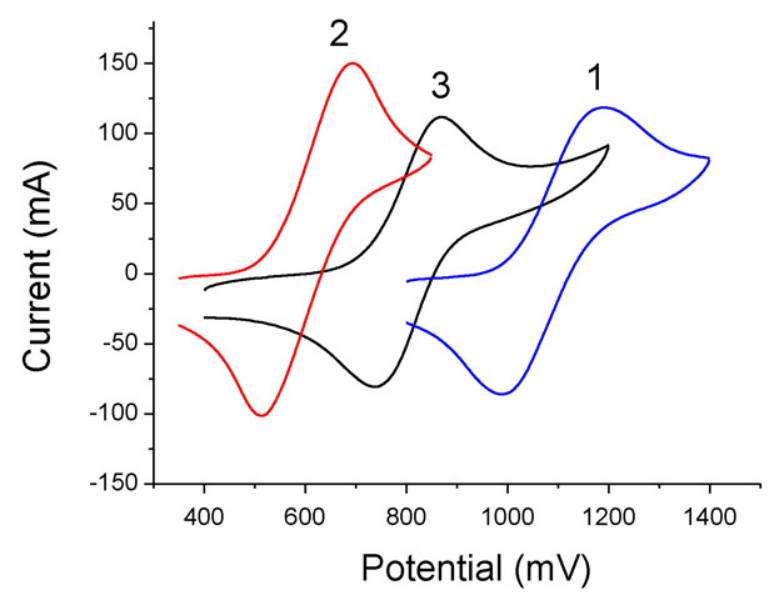

Fig. 2. Cyclic voltammograms of $\mathrm{Ru}(\mathrm{II})$ complexes 1,2 and 3. Conditions: $\mathrm{CH}_{2} \mathrm{Cl}_{2}, 0.10 \mathrm{M}$ $\mathrm{Bu}_{4} \mathrm{NClO}_{4}$ as supporting electrolyte, scan rate $100 \mathrm{mV} \mathrm{s}{ }^{-1}$; working and auxiliary electrodes stationary Pt foils, and $\mathrm{Ag} / \mathrm{AgCl}$ as reference electrode. of the two phosphorus atoms of dppb. The precursor complex cis$\left[\mathrm{RuCl}_{2}(\mathrm{dppb})\right.$ (bipy)] shows a pair of doublets at 32.0 and $43.0 \mathrm{ppm}$ with the high field signal corresponding to the $\mathrm{P}$ trans $\mathrm{N}$, as previously described [40]. These assignments are based on an empirical linear correlation established between crystallographic determined Ru-P distances in a series of Ru-dppb complexes and the corresponding ${ }^{31} \mathrm{P}$ chemical shift observed in solution, in which the chemical shift become more high-field with increasing Ru-P bond length [50]. In view of this information, we suggest that in complex 1 the high-field doublet belongs to the $\mathrm{P}$ trans to nitrogen from bipy, because the Ru-P2 distance of 2.3299(9) $\AA$ (trans bipy) is longer than that observed for the Ru-P1 trans of nitrogen of the 2-MT ligand [2.3069(9) Å].

In contrast, only one singlet is observed in the ${ }^{31} \mathrm{P}\left\{{ }^{1} \mathrm{H}\right\}$ NMR spectra of complexes $\mathbf{2}$ and 3, due to the presence of two equivalent $\mathrm{PPh}_{3}$ phosphorus atoms (Table 1). For complex 2 the singlet signal at $54.2 \mathrm{ppm}$ is typical of $\mathrm{PPh}_{3}$ trans to nitrogen of $\mathrm{N}$-heterocyclic ligands as observed for similar compounds such as the cis-[Ru(pymS $\left.)_{2}\left(\mathrm{PPh}_{3}\right)_{2}\right]$, pymS $=$ deprotonated 2-mercaptopyrimidine [51]. For complex $\mathbf{3}$ the singlet is observed at $33.3 \mathrm{ppm}$, a chemical shift in low field is shifted when compared to cis-[ $\mathrm{RuCl}_{2}\left(\mathrm{PPh}_{3}\right)_{2}$ (bipy)], where a singlet is presented at $21.5 \mathrm{ppm}$ [52]. These values are typical of $\mathrm{PPh}_{3}$ trans to $\mathrm{PPh}_{3}$ as observed for a series of ruthenium compounds $[53,54]$. The ${ }^{1} \mathrm{H}$ NMR spectrum of metal-free tzdtH in $\mathrm{CDCl}_{3}$ displayed a broad singlet corresponding to the proton of the $\mathrm{N}-\mathrm{H}$ group around $7.30 \mathrm{ppm}$ and a pair of triplets in the range $3.50-4.00 \mathrm{ppm}$ corresponding to the methylenic protons.

Table 1

${ }^{31} \mathrm{P}\left\{{ }^{1} \mathrm{H}\right\}$ NMR and cyclic voltammetry data for complexes $\mathbf{1 - 3}$.

\begin{tabular}{lllll}
\hline Complex & $\delta(\mathrm{ppm})$ & ${ }^{2} \mathrm{JP}_{\mathrm{P}}(\mathrm{Hz})$ & $\mathrm{E} 1 / 2(\mathrm{mV})$ & $\Delta \mathrm{E}_{\mathrm{p}}(\mathrm{mV})$ \\
\hline $\mathbf{1}$ & $43.2(\mathrm{~d}) ; 44.6(\mathrm{~d})$ & 35.1 & 1082 & 135 \\
$\mathbf{2}$ & $54.2(\mathrm{~s})$ & - & 602 & 176 \\
$\mathbf{3}$ & $33.3(\mathrm{~s})$ & - & 860 & 132
\end{tabular}


For complexes 1-3 the signal at 7.30 is absent confirming that tzdtH is coordinated to $\mathrm{Ru}(\mathrm{II})$ in a deprotonated form and the methylenic protons appeared as multiplet signals in the range $2.30-3.40$ ppm, considerably high-field shifted when compared with free-ligand. In the aromatic region protons of $\mathrm{dppb}$ (complex $\mathbf{1}$ ) and $\mathrm{PPh}_{3}$ (complexes 2 and 3 ) displayed the typical pattern of multiplet signals for ortho, meta and para hydrogens of the aromatic rings in ranges of 6.38-7.45; 7.10-7.32 and 7.20-7.35 ppm, respectively. In addition, complexes 1 and 3 exhibited the expected deshielded doublets corresponding to the ortho hydrogens of the bipy ligands at 8.96 ; 8.74 and 9.75; $9.02 \mathrm{ppm}$, respectively. The ${ }^{13} \mathrm{C}$ NMR spectra of complexes 1-3 displayed signals around 183-181 ppm, depending on the complex, typical of the CS coordinated group. This signal is shielded compared with that observed for the free ligand which occurs at $201.7 \mathrm{ppm}$, indicating that sulfur is coordinated to the metal. In addition, complexes displayed signals in the range 57.4-55.3 and 32.0-31.7 ppm, typically assigned to carbon atoms of the $\mathrm{N}-\mathrm{CH}_{2}$ and $\mathrm{S}-\mathrm{CH}_{2}$ groups of the thiazolidine ring, respectively.

\subsection{X-ray crystal structures}

Suitable crystals for a single crystal X-ray structure determination were obtained by slow evaporation of a chloroform solution. The MERCURY plots in Fig. 3 show that these complexes possess a distorted octahedral geometry. Crystal data collections and structure refinement parameters are summarized in Table 1S. The crystallographic analysis of metal-free tzdtH described in the literature shows that C1-S1 is a double bond, while C1-N1 single-bond [54]. When tzdtH is coordinated to $\mathrm{Ru}$, the length of these bonds significantly changes in which the $\mathrm{C} 1-$ $\mathrm{S} 1$ is longer whereas $\mathrm{C} 1-\mathrm{N} 1$ is shorter in all the complexes. This suggests that the ligand adopts the canonical form (III) depicted in Fig. 1. In the crystal structure of complex 3, the Ru-P bond lengths are longer than the other two complexes, possible due to the P to P trans influence. In contrast, the Ru-N1 length in $\mathbf{3}$ is shorter than that the observed for complexes $\mathbf{1}$ and $\mathbf{2}$, because of the $\mathrm{P}$ to $\mathrm{N}$ trans influence which slightly affects the Ru-N bond length.

When we analyze the $\mathrm{tzdt}^{-}$conformation, a planar conformation in complexes $\mathbf{1}$ and $\mathbf{3}$ is observed, while in complex $\mathbf{2}$ a twisted ring is observed in the ligand structure. Due to the intermolecular interaction and crystal packing, the free tzdtH in solid state adopts either a distorted or a planar conformation. In the crystal structure of the neutral complex $\mathbf{2}$, a sulfur $\cdots$ sulfur contact is observed, which explains the tzdtH distorted conformation. The distance of S $\cdots \mathrm{S}$ atoms in the structure of complex 2 is at $3.543 \AA$ as shown in Fig. 4, being shorter than the sum of the van der Waals radius ( $3.60 \AA$ ).

To examine the spatial arrangement of Ru complexes, the intermolecular contacts of each crystal structure were determined by using the Hirshfeld surfaces and their corresponding 2D-fingerprint plots (Supplementary material). The relative contribution of the intermolecular contacts present in these complexes shares interesting structural features. In complex (1), the contribution is: $\mathrm{H} \cdots \mathrm{H}(55.1 \%), \mathrm{C} \cdots \mathrm{H}$ $(17.2 \%), \mathrm{F} \cdots \mathrm{H}(15.9 \%), \mathrm{S} \cdots \mathrm{H}(7.9 \%), \mathrm{C} \cdots \mathrm{C}(1.4 \%), \mathrm{C} \cdots \mathrm{F}(0.5 \%), \mathrm{S} \cdots \mathrm{F}$ $(0.4 \%)$, and $\mathrm{N} \cdots \mathrm{H}(0.4 \%)$. In comparison to complex 1 , the intermolecular contribution found in $\mathbf{2}$ is slightly different $[\mathrm{H} \cdots \mathrm{H}(63.6 \%), \mathrm{C} \cdots \mathrm{H}(17.5 \%)$,

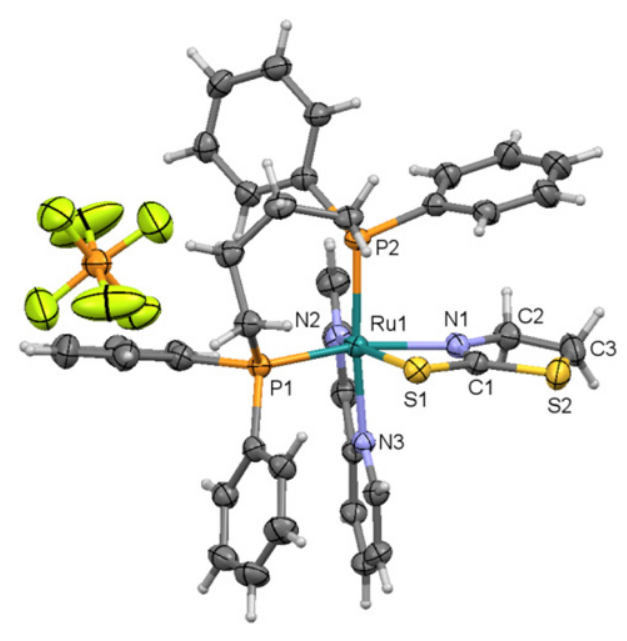

(1)

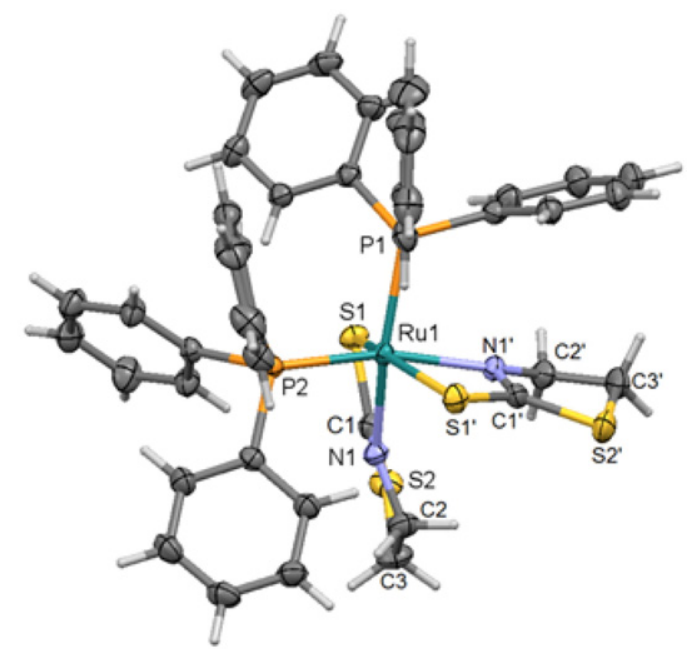

(2)

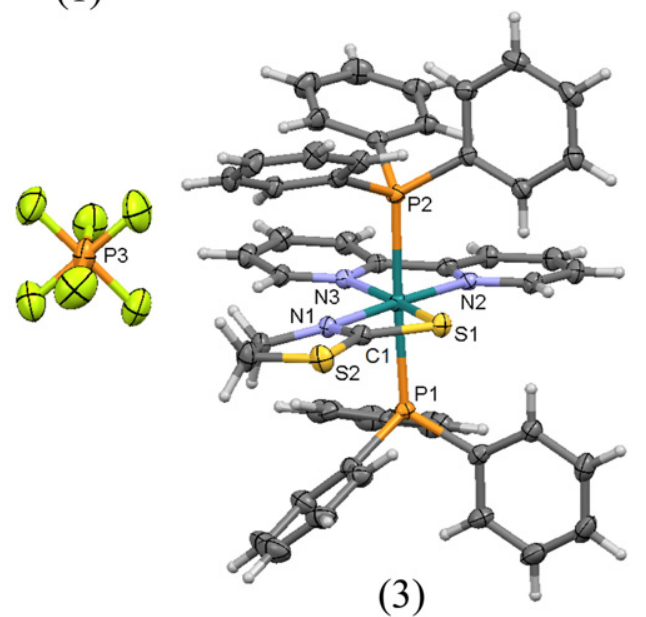

Fig. 3. Crystal structures of complexes 1, $\mathbf{2}$ and $\mathbf{3}$ with selected atoms labeled. Ellipsoids are represented at $30 \%$ of probability. 


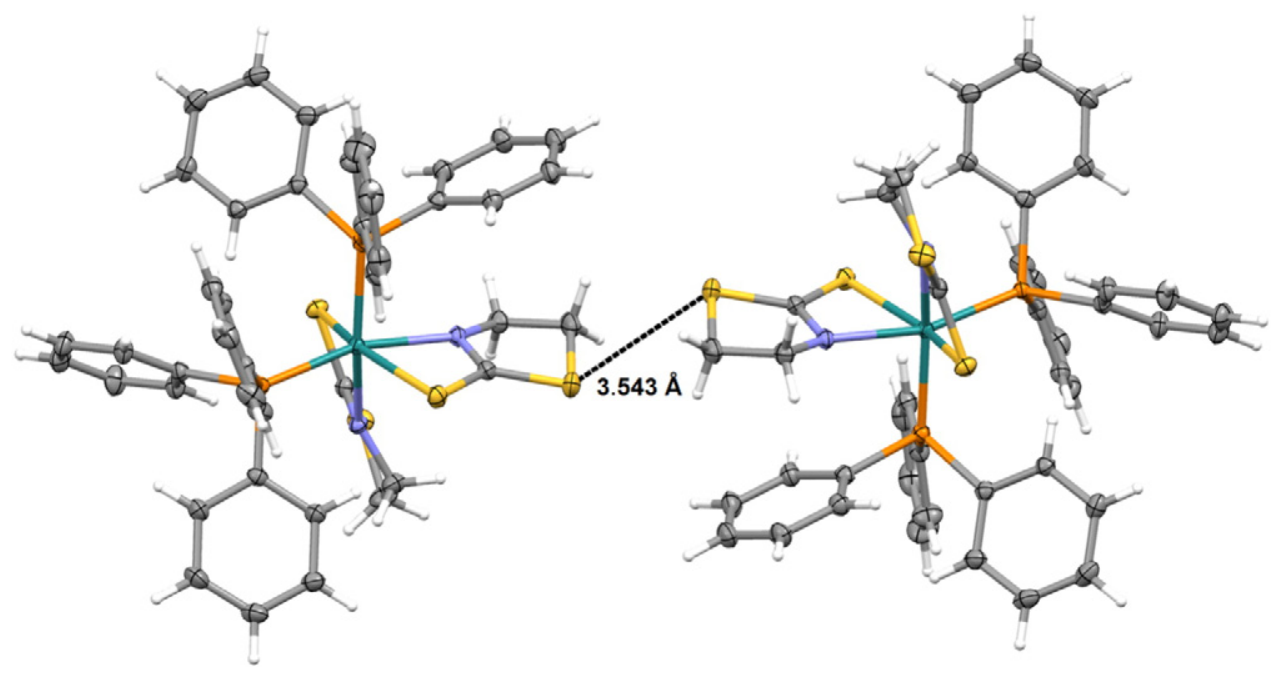

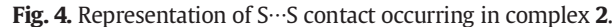

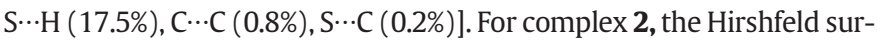
face analysis highlights the intermolecular contacts between $S \cdots S$ with contribution of $0.3 \%$, which is absent in other complexes, this kind of contact can be seen in Fig. 4. The contribution to Hirshfeld surface in complex $3[\mathrm{H} \cdots \mathrm{H}(48.7 \%), \mathrm{C} \cdots \mathrm{H}(19.0 \%), \mathrm{F} \cdots \mathrm{H}(13.7 \%), \mathrm{S} \cdots \mathrm{H}(6.3 \%)$, C...C (0.6\%)] is similar to that observed in complex 1. In all of them, the $\mathrm{H} \cdots \mathrm{H}$ contacts compose about $50 \%$ of the Hirshfeld surface, evidencing the importance of van der Waals forces to crystal packing stabilization.

\subsection{Pharmacological evaluation}

\subsubsection{Cytotoxicity in cancer cells and ctDNA binding}

In vitro cytotoxicity against DU-145 prostate and MCF-7 breast cancer cells was examined $48 \mathrm{~h}$ after incubation with drugs and the results were expressed by determining the $\mathrm{IC}_{50}$ values. Cisplatin was the reference cytotoxic drug. For comparison reason only, metal-free ligands tzdtH, dppb, bipy and $\mathrm{PPh}_{3}$ were tested as well. The results are summarized in Table 2.

All the complexes displayed cytotoxicity against cancer cells, while none metal-free ligands were cytotoxic in concentrations up to $200 \mu \mathrm{M}$. These observations strongly suggests that $\mathrm{Ru}(\mathrm{II})$ associated with the ligands are responsible for the cytotoxicity in cancer cells. Importantly, the $\mathrm{Ru}(\mathrm{II})$ complexes were more active than cisplatin. A comparison between the complexes revealed that compound $\mathbf{1}$ is potent against the two cancer cell lines, while $\mathbf{2}$ is more cytotoxic against breast than prostate cells. Complex $\mathbf{1}$ was particularly more potent against prostate cells, while compound $\mathbf{3}$ was against breast cells. Complex $\mathbf{2}$ was less active among the complexes.

Based on the cytotoxicity of these Ru(II) complexes against cancer cells, it was hypothesized that these complexes may interact with ctDNA. To verify this, the interaction with ctDNA was studied via spectroscopic titration (Fig. 5a). Under the presence of the $\mathrm{Ru}$ (II) complexes, a ctDNA hypochromism in the range of $29-35 \%$ was observed, which indicates that metal complexes form a ternary complex with ctDNA. In addition, the binding constant $\left(\mathrm{K}_{\mathrm{b}}\right)$ were determined and the respective values found were: 1.0, 1.7 and $4.9 \times 10^{3} \mathrm{M}^{-1}$ for complexes $\mathbf{1}, \mathbf{2}$ and 3. These values indicate a weak interaction with ctDNA when compared to a classical ctDNA intercalator ethidium bromide $\left(\mathrm{K}_{\mathrm{b}} 10^{6} \mathrm{M}^{-1}\right)$ [55]. Interestingly, complex 1 was the most active anticancer drug, but it presented lower ctDNA than complex 3, which was less cytotoxic. Moreover, viscosity analysis of ctDNA-binding revealed that viscosity is not modified when the concentration of a $\mathrm{Ru}$ (II) complex increases. This supports the idea that ruthenium complexes have a weak

Table 2

Cytotoxicity and antitrypanosomal activities of complexes 1-3, metal-free tzdtH and reference drugs.

\begin{tabular}{|c|c|c|c|c|c|}
\hline \multirow[t]{2}{*}{ Compounds } & \multicolumn{3}{|c|}{$\mathrm{IC}_{50} \pm$ S.E.M. $(\mu \mathrm{M})$} & \multirow[t]{2}{*}{ J774 macrophages, $\mathrm{CC}_{50} \pm$ S.E.M. $(\mu \mathrm{M})^{\mathrm{c}}$} & \multirow[t]{2}{*}{$\mathrm{SI}^{\mathrm{d}}$} \\
\hline & $\mathrm{DU}-145^{\mathrm{a}}$ & MCF-7 $7^{\mathrm{a}}$ & T. cruzi trypomastigotes ${ }^{b}$ & & \\
\hline tzdtH & $>200$ & $>200$ & $>10$ & $>10$ & - \\
\hline 1 & $0.3 \pm 0.2$ & $1.1 \pm 0.9$ & $0.23 \pm 0.09$ & $1.0 \pm 0.16$ & 3.7 \\
\hline 2 & $4.9 \pm 0.2$ & $0.98 \pm 0.2$ & $>10$ & $>10$ & - \\
\hline 3 & $0.9 \pm 0.9$ & $3.3 \pm 1.3$ & $0.010 \pm 0.001$ & $0.34 \pm 0.3$ & 34 \\
\hline Cisplatin & $2.0 \pm 0.5$ & $8.9 \pm 2.6$ & - & - & - \\
\hline Benznidazole & - & - & $10.6 \pm 0.8$ & - & - \\
\hline Gentian violet & - & - & - & $0.82 \pm 0.1$ & - \\
\hline Dppb & $>200$ & $>200$ & - & - & - \\
\hline $\mathrm{PPh}_{3}$ & $180.1 \pm 1.6$ & $>200$ & - & - & - \\
\hline Bipy & $>200$ & $>200$ & - & - & - \\
\hline
\end{tabular}

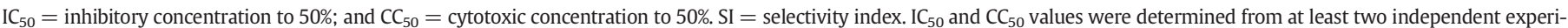
ments using concentration in triplicate.

a Determined in cancer cells after $48 \mathrm{~h}$ incubation with drugs.

b Determined in Y strain of T. cruzi trypomastigotes after $24 \mathrm{~h}$ incubation.

c Determined in J774 macrophage cell lines after $72 \mathrm{~h}$ incubation.

d SI determined as ( $\mathrm{CC}_{50}$ macrophages $) /\left(\mathrm{IC}_{50}\right.$ T. cruzi). 
(a)
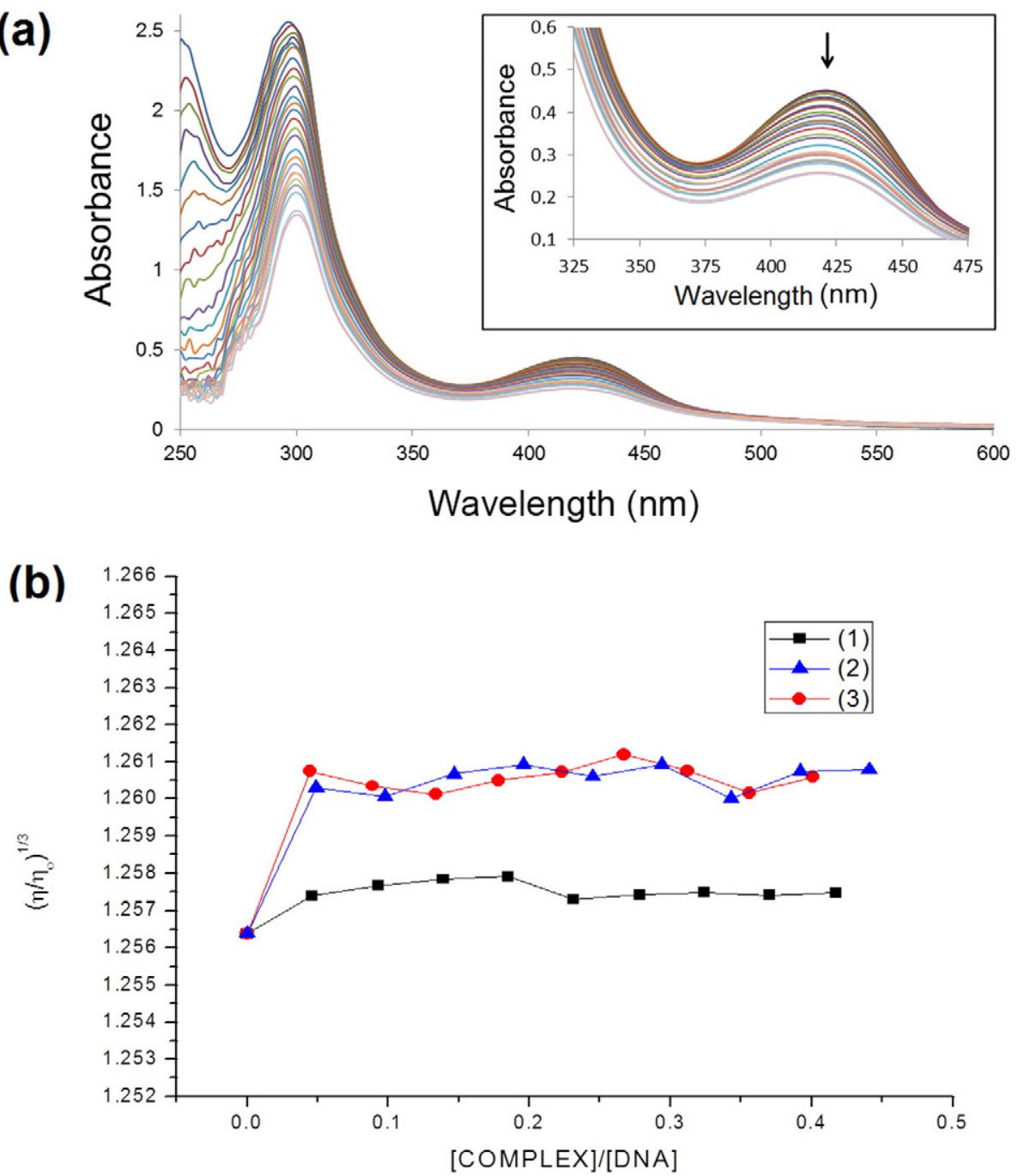

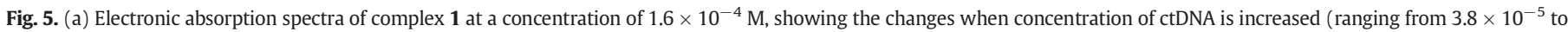

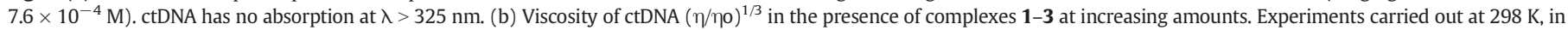
a Tris- $\mathrm{HCl}$ buffer, $\mathrm{pH} 7.4$.

interaction, possibly by an electrostatic mode [56]. A plausible interpretation for this observation is that the binding of $\mathrm{Ru}(\mathrm{II}) \mathrm{com}$ plexes to ctDNA is not via intercalation, due to the absence of planar ligands.

\subsubsection{Antiparasitic activity}

The antiparasitic evaluation against bloodstream trypomastigotes of T. cruzi parasite revealed that metal-free tzdtH and complex 2 have no activity in a concentration up to $10 \mu \mathrm{M}$. In contrast, complexes $\mathbf{1}$ and $\mathbf{3}$
(A)

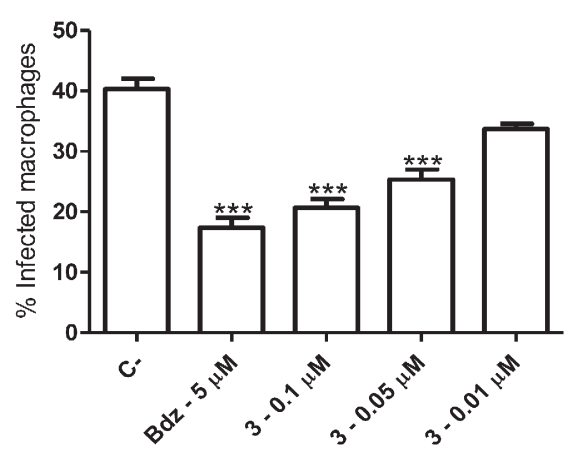

(B)

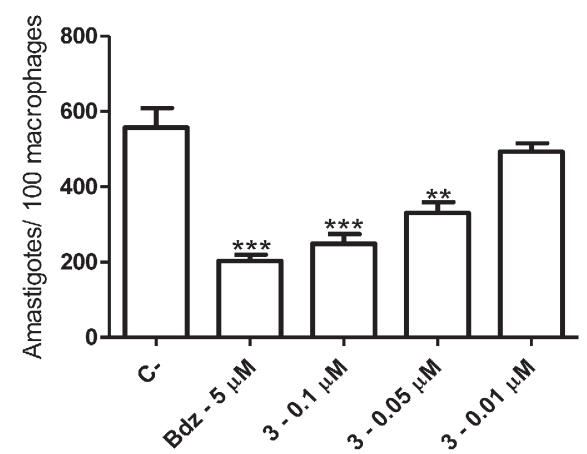

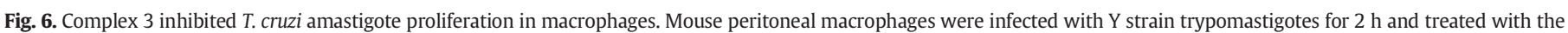

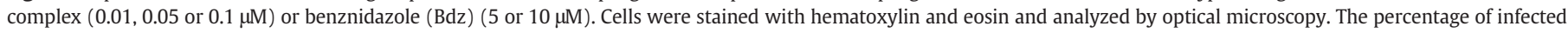

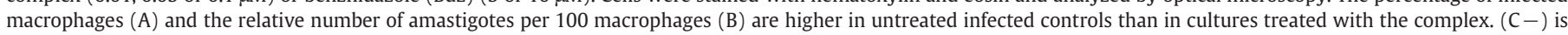
negative control. Values represent the mean \pm S.E.M. of triplicates. ${ }^{* *} \mathrm{P}<0.01$; and ${ }^{* * *} \mathrm{P}<0.001$ compared to untreated cultures. 
exhibited strong activity (Table 2). Complex 3 displayed the highest antiparasitic activity, being more potent than benznidazole, the reference antiparasitic drug. Additionally, complex 3 had little effect on J774 macrophage viability, therefore showing that the antiparasitic activity for this complex was achieved with great selectivity index. Regarding the structure-activity relationships, active antiparasitic complexes containing a bipy ligand were observed, while complex 2 lacking bipy was inactive. Therefore, these observations suggest that the presence of bipy as well as a positive charge present in the structures of complexes $\mathbf{1}$ and 3 contribute to antiparasitic activity.

\subsubsection{Evaluation in T. cruzi-infected macrophages}

After observing that complex $\mathbf{3}$ has potent and selective activity against the extracellular parasite, its antiparasitic activity against the intracellular form of T. cruzi was investigated (Fig. 6). In comparison to untreated infected macrophages, complex 3 treatment reduced the percentage of infected macrophages. Moreover, this treatment reduced the mean number of amastigotes per 100 macrophages. Importantly, complex 3 at $0.1 \mu \mathrm{M}$ has comparable antiparasitic activity to benznidazole, the positive control. Therefore, these results show that this complex has antiparasitic activity against the intracellular and proliferative amastigote form. Since amastigote proliferation is pivotal within parasite cell cycle, it is plausible that these compounds impair the parasite cell cycle development inside host cells.

Given this strong antiparasitic activity, it was investigated whether the $\mathrm{Ru}(\mathrm{II})$ complexes have enhanced activity in drug combination with benznidazole. As shown in Fig. 7, drug combination of benznidazole at $5 \mu \mathrm{M}$ plus complex 3 at $0.05 \mu \mathrm{M}$ reduced the percentage of infected macrophages as well as the number of amastigotes more than each drug alone (Fig. 7, panels A, B). Importantly, the drug combination displayed stronger activity than benznidazole alone at a high concentration $(10 \mu \mathrm{M})$. When the concentration of complex 3 was increased at $0.1 \mu \mathrm{M}$ and added in combination to benznidazole at $5 \mu \mathrm{M}$, in practice no intracellular parasites were observed (Fig. 7, panels $\mathrm{C}, \mathrm{D})$. These results indicate that drug combination of benznidazole and complex $\mathbf{3}$ has enhanced antiparasitic activity.

\subsubsection{Parasite cell death}

After ascertaining the antiparasitic activity of complex $\mathbf{3}$, it was investigated how this complex causes parasite cell death. In comparison to untreated trypomastigotes (Fig. 8, panel A), complex 3 treatment lead to single PI staining and double PI + annexin V staining, which are characteristics of necrosis and late apoptosis, respectively. As observed by comparing panels B-D, complex $\mathbf{3}$ causes cell death in a concentration-dependent manner. Therefore, the Ru complex causes parasite cell death mainly by inducing necrosis.

\section{Conclusions}

Here we demonstrated the great chemical versatility of $\mathrm{tzdtH}$, which is able to react with phosphine-, diamine- and phosphine/diamine-Ru precursors. The X-ray crystallography analyses revealed the exact structures of the complexes $\left[\mathrm{Ru}(\mathrm{tzdt})(\mathrm{bipy})(\mathrm{dppb}) \mathrm{PF}_{6}\right.$ (1), cis$\left[\mathrm{Ru}(\mathrm{tzdt})_{2}\left(\mathrm{PPh}_{3}\right)_{2}\right](\mathbf{2})$ and trans-[Ru(tzdt) $\left.\left(\mathrm{PPh}_{3}\right)_{2}(\mathrm{bipy})\right] \mathrm{PF}_{6}(\mathbf{3})$ and highlighted that the tzdt heterocyclic ring can assume a planar or twisted conformation under metal coordination. The electrochemical profile of these Ru complexes pointed out that tzdt provided resistance toward oxidation than the precursor complexes. These complexes exhibited strong anticancer and antiparasitic activity, while the metal-free tzdtH do not provoke the same outcome. Regarding the anticancer activity,
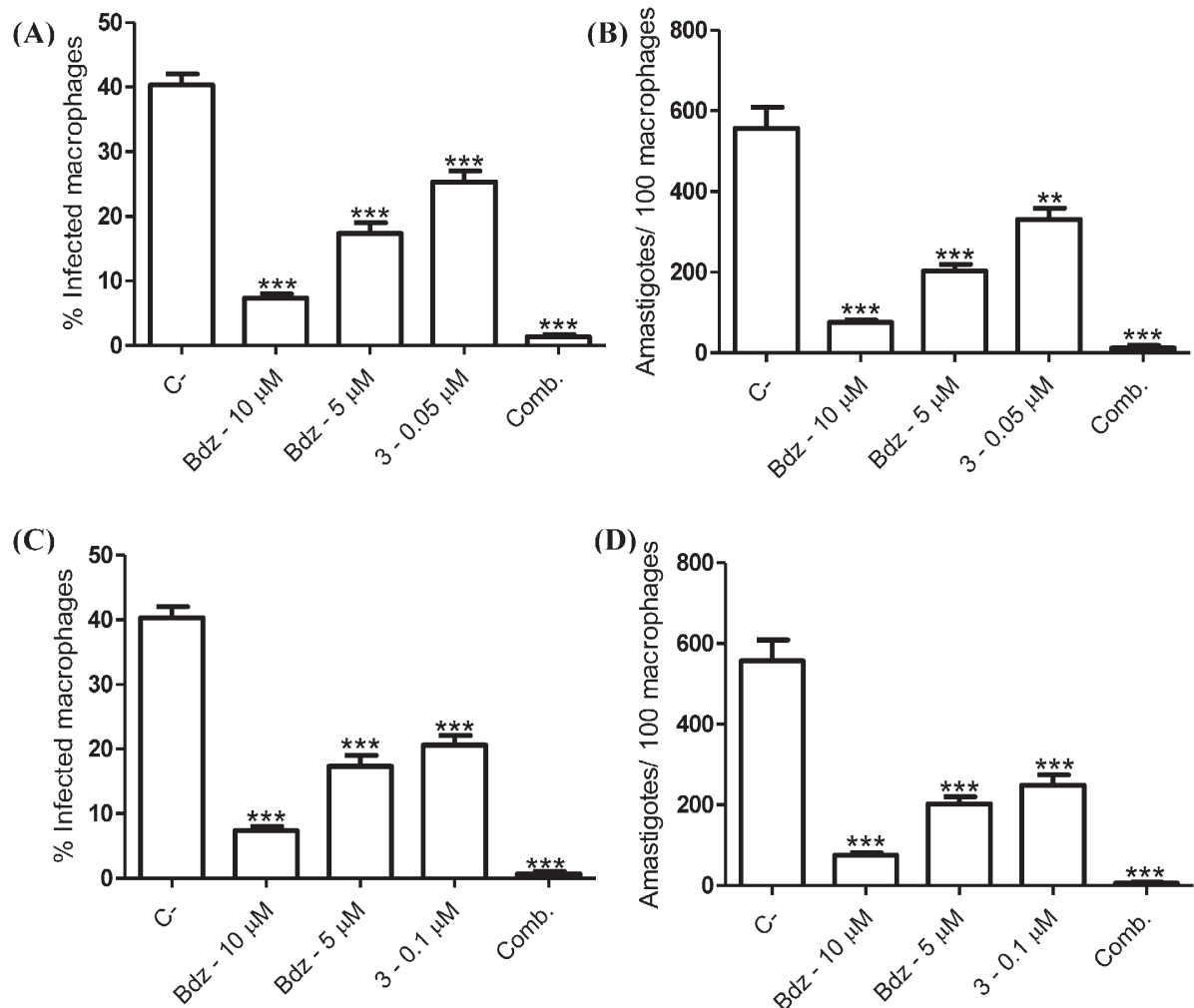

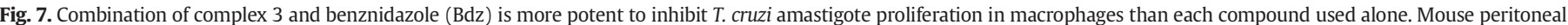

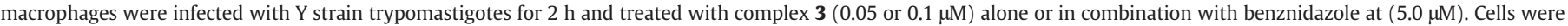

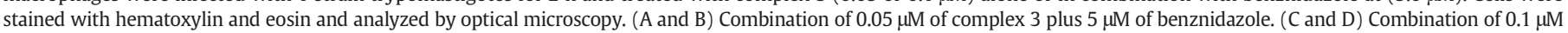
of complex 3 plus $5 \mu \mathrm{M}$ of benznidazole. $\left(\mathrm{C}-\right.$ ) is negative control. Values represent the mean \pm S.E.M. of triplicates. ${ }^{* * *} \mathrm{P}<0.001$ compared to untreated cultures. 
A

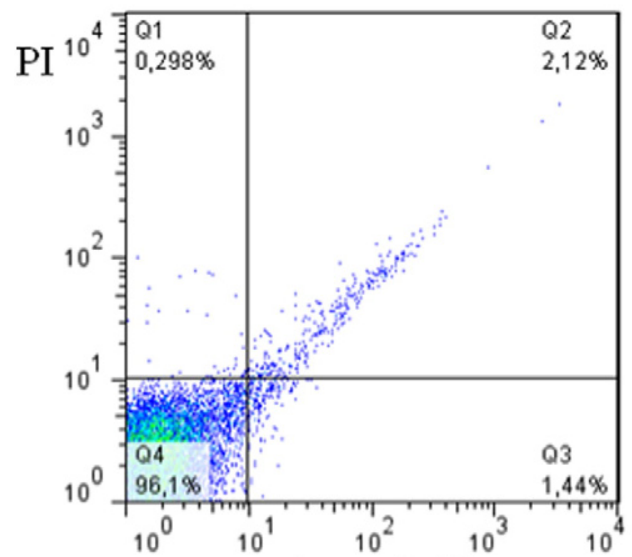

C

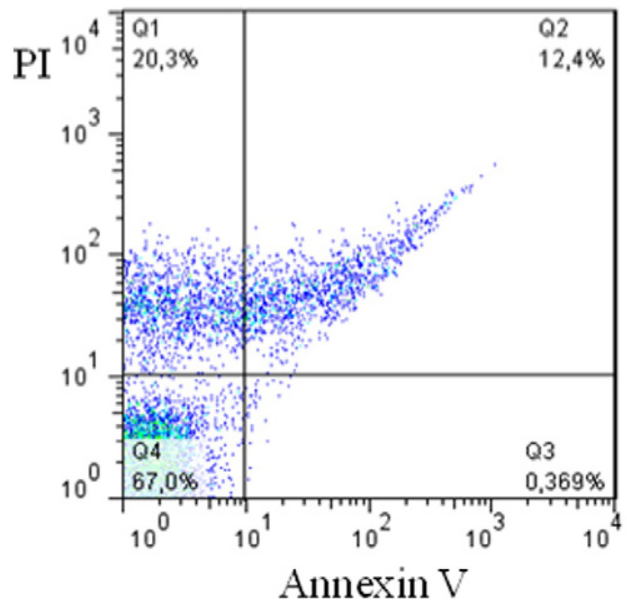

B
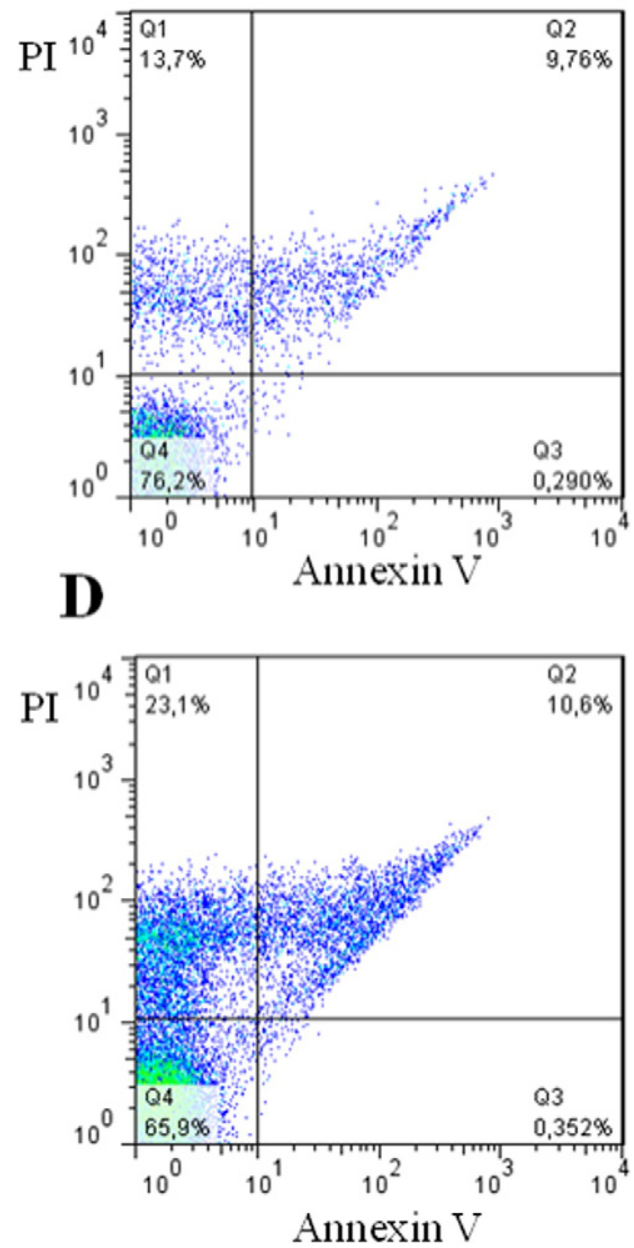

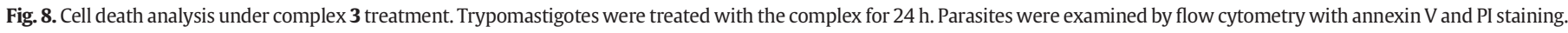

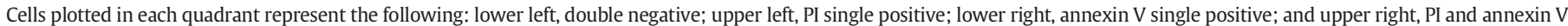
double positive. (A) Untreated; (B) complex at $0.01 \mu \mathrm{M}$; (C) complex at $0.015 \mu \mathrm{M}$; and (D) complex at $0.02 \mu \mathrm{M}$.

the new complexes exhibited cytotoxicity against prostate and breast cancer cells. They were more potent than cisplatin and more cytotoxic for cancer than normal cells (macrophages), indicating a degree of selectivity. Regarding the antiparasitic activity against $T$. cruzi, these complexes exhibited a broad spectrum of action (extracellular, intracellular forms). Flow cytometry analysis revealed that complex $\mathbf{3}$ destroys parasite cells, indicating this is more likely a parasiticidal than a cytostatic drug. These complexes arrested the parasite cell cycle and strongly affected the intracellular development and ultimately caused irreversible parasite death through a necrotic process. An important aspect in the anticancer and antiparasitic therapy is the drug combination. Here it was observed that Ru(II) complexes exhibit enhanced antiparasitic activity when given in combination with the antiparasitic drug benznidazole. This points out that these complexes are suitable molecules for drug combination compositions.

\section{Acknowledgments}

We thank the Brazilian Agencies of Research: CNPq, CAPES, FAPESB and FAPESP (grant number 2012/06013-4). R.S.C. thanks FAPESP (Fundação de Amparo à Pesquisa do Estado de São Paulo) for a postdoctoral fellowship (grant numbers 2009/08131-1 and 2013/265594). C.S.M. is receiving a FAPESB (Fundação de Amparo à Pesquisa do Estado da Bahia) (Grant 0417/2012) scholarship. G.V.P. thanks FAPEMIG (Fundação de Amparo à Pesquisa do Estado de Minas Gerais) (Grant
APQ-04010-10). The authors acknowledge Dr. Marília I. F. Barbosa and Prof. Javier Ellena for the helpful discussions during the preparation of the manuscript.

\section{Supplementary data}

Coordinates and other crystallographic data have been deposited with the deposition codes CCDC 1037025, CCDC 1037026 and CCDC 1037027, for 1, 2 and 3, respectively. Copies of this information may be obtained from The Director, CCDC, 12 Union Road, Cambridge CB2 1EZ, UK, Fax: + 441233 336,033, E-mail: deposit@ccdc.cam.ac.uk or www.ccdc.cam.ac.uk. Supplementary data to this article can be found online at http://dx.doi.org/10.1016/j.jinorgbio.2015.12.024.

\section{References}

[1] B.L.D.M. Bruecher, G. Lyman, R. van Hillegersberg, R.E. Pollock, F. Lordick, H. Yang, T. Ushijima, K.G. Yeoh, T. Skricka, W. Polkowski, G. Wallner, V. Verwaal, A. Garofalo, D. D'Ugo, F. Roviello, H.U. Steinau, T.J. Wallace, M. Daumer, N. Maihle, T.J. Reid, M. Ducreux, Y. Kitagawa, A. Knuth, B. Zilberstein, S.R. Steele, I.S. Jamall, I.S. Jamall, BMC Cancer 14 (2014) 186.

[2] K.C. Oeffinger, S.S. Baxi, D.N. Friedman, C.S. Moskowitz, Semin. Oncol. 40 (2013) 676-689.

[3] J. Ferlay, E. Steliarova-Foucher, J. Lortet-Tieulent, S. Rosso, J.W.W. Coebergh, H. Comber, D. Forman, F. Bray, Eur. J. Cancer 49 (2013) 1374-1403.

[4] N.J. Wheate, S. Walker, G.E. Craig, R. Oun, Dalton Trans. 39 (2010) 8113-8127.

[5] S. Dasari, P.B. Tchounwou, Eur. J. Pharmacol. 740 (2014) 364-378. 
[6] J. Cetnar, G. Wilding, D. McNeel, N.K. LoConte, T.A. McFarland, J. Eickhoff, G. Liu, Urol. Oncol.-Sem. Orig. Investig. 31 (2013) 436-441.

[7] K.D. Mjos, C. Orvig, Chem. Rev. 114 (2014) 4540-4563.

[8] R.S. Correa, K.M.d. Oliveira, F.G. Delolo, A. Alvarez, R. Mocelo, A.M. Plutin, M.R. Cominetti, E.E. Castellano, A.A. Batista, J. Inorg. Biochem. 150 (2015) 63-71.

[9] S. Pillozzi, L. Gasparoli, M. Stefanini, M. Ristori, M. D'Amico, E. Alessio, F. Scaletti, A. Becchetti, A. Arcangeli, L. Messori, Dalton Trans. 43 (2014) 12150-12155.

[10] R. Trondl, P. Heffeter, C.R. Kowol, M.A. Jakupec, W. Berger, B.K. Keppler, Chem. Sci. 5 (2014) 2925-2932.

[11] C. Scolaro, A. Bergamo, L. Brescacin, R. Delfino, M. Cocchietto, G. Laurenczy, T.J. Geldbach, G. Sava, P.J. Dyson, J. Med. Chem. 48 (2005) 4161-4171.

[12] C.G. Hartinger, N. Metzler-Nolte, P.J. Dyson, Organometallics 31 (2012) 5677-5685

[13] M.V. Babak, S.M. Meier, K.V.M. Huber, J. Reynisson, A.A. Legin, M.A. Jakupec, A. Roller, A. Stukalov, M. Gridling, K.L. Bennett, J. Colinge, W. Berger, P.J. Dyson, G. SupertiFurga, B.K. Keppler, C.G. Hartinger, Chem. Sci. 6 (2015) 2449-2456.

[14] P.J. Hotez, D.H. Molyneux, A. Fenwick, J. Kumaresan, S.E. Sachs, J.D. Sachs, L. Savioli, N. Engl. J. Med. 357 (2007) 1018-1027.

[15] I. Ribeiro, A.-M. Sevcsik, F. Alves, G. Diap, R. Don, M.O. Harhay, S. Chang, B. Pecoul, PLoS Negl. Trop. Dis. 3 (2009)

[16] J.A. Urbina, Acta Trop. 115 (2010) 55-68

[17] C.A. Morillo, J.A. Marin-Neto, A. Avezum, S. Sosa-Estani, A. Rassi-Jr, F. Rosas, E Villena, R. Quiroz, R. Bonilla, C. Britto, F. Guhl, E. Velazquez, L. Bonilla, B. Meeks, P. Rao-Melacini, J. Pogue, A. Mattos, J. Lazdins, A. Rassi, S.J. Connolly, S. Yusuf, BENEFIT Investigators, N. Engl. J. Med. 373 (2015) 1295-1306.

[18] M. Navarro, C. Gabbiani, L. Messori, D. Gambino, Drug Discov. Today 15 (2010) 1070-1078.

[19] D. Gambino, Coord. Chem. Rev. 255 (2011) 2193-2203.

[20] D.R. Moreira, A.C. Leite, R.R. dos Santos, M.B. Soares, Curr. Drug Targets 10 (2009) 212-231.

[21] F.B. Nascimento, G. Von Poelhsitz, F.R. Pavan, D.N. Sato, C.Q.F. Leite, H.S. Selistre-deAraújo, J. Ellena, E.E. Castellano, V.M. Deflon, A.A. Batista, J. Inorg. Biochem. 102 (2008) 1783-1789.

[22] F.R. Pavan, G. Von Poelhsitz, M.I.F. Barbosa, S.R.A. Leite, A.A. Batista, J. Ellena, L.S. Sato, S.G. Franzblau, V. Moreno, D. Gambino, C.Q.F. Leite, Eur. J. Med. Chem. 46 (2011) 5099-5107.

[23] E.R. dos Santos, M.A. Mondelli, L.V. Pozzi, R.S. Correa, H.S. Salistre-de-Araujo, F.R Pavan, C.Q.F. Leite, J. Ellena, V.R.S. Malta, S.P. Machado, A.A. Batista, Polyhedron 51 (2013) 292-297.

[24] F.R. Pavan, G. Von Poelhsitz, L.V.P. da Cunha, M.I.F. Barbosa, S.R.A. Leite, A.A. Batista, S.H. Cho, S.G. Franzblau, M.S. de Camargo, F.A. Resende, E.A. Varanda, C.Q.F. Leite, PLoS One 8 (2013).

[25] M.A. Mondelli, A.E. Graminha, R.S. Correa, M.M. da Silva, A.P. Carnizello, G. Von Poelhsitz, J. Ellena, V.M. Deflon, G.F. Caramori, M.H. Torre, D.C. Tavares, A.A Batista, Polyhedron 68 (2014) 312-318.

[26] M.I.F. Barbosa, R.S. Corrêa, K.M.d. Oliveira, C. Rodrigues, J. Ellena, O.R. Nascimento V.P.C. Rocha, F.R. Nonato, T.S. Macedo, J.M. Barbosa-Filho, M.B.P. Soares, A.A Batista, J. Inorg. Biochem. 136 (2014) 33-39.

[27] M.A.P. Almeida, F.B.d. Nascimento, A.E. Graminha, A.G. Ferreira, J. Ellena, F.M.d.S Mello, A.P.d. Lima, E.d.P. Silveira-Lacerda, A.A. Batista, Polyhedron 81 (2014) 735-742.
[28] R. Corona-Sanchez, R.A. Toscano, M. Carmen Ortega-Alfaro, C. Sandoval-Chavez, J.G. Lopez-Cortes, Dalton Trans. 42 (2013) 11992-12004.

[29] L. Li, K. Du, Y. Wang, H. Jia, X. Hou, H. Chao, L. Ji, Dalton Trans. 42 (2013) 11576-11588.

[30] E.S. Raper, R.E. Oughtred, I.W. Nowell, Inorg. Chim. Acta Lett. 77 (1983) L89-L93.

[31] U.M. Rabie, M.H.M. Abou-El-Wafa, H. Nassar, Spectrochim. Acta A 78 (2011) 512-517.

[32] C. Abbehausen, R.E.F. de Paiva, A.L.B. Formiga, P.P. Corbi, Chem. Phys. 408 (2012) 62-68.

[33] E.S. Raper, J.R. Creighton, W. Clegg, L. Cucurull-Sanchez, M.N.S. Hill, P.D. Akrivos, Inorg. Chim. Acta 271 (1998) 57-64.

[34] P.G. Jones, S. Friedrichs, Acta Crystallogr. C 62 (2006) (M623-M7).

[35] D. Atzei, D. De Filippo, A. Rossi, M. Porcelli, Spectrochim. Acta A 57 (2001) 1073-1083.

[36] W.S. Sheldrick, C. Landgrafe, Inorg. Chim. Acta 208 (1993) 145-151.

[37] J.D.E.T. Wilton-Ely, M. Wang, D.M. Benoit, D.A. Tocher, Eur. J. Inorg. Chem. (2006) 3068-3078.

[38] S.L. Queiroz, A.A. Batista, G. Oliva, M. Gambardella, R.H.A. Santos, K.S. MacFarlane, S.J. Rettig, B.R. James, Inorg. Chim. Acta 267 (1998) 209-221.

[39] T.A. Stephens, G. Wilkinson, J. Inorg. Nucl. Chem. 28 (1966) 945-956.

[40] A.A. Batista, M.O. Santiago, C.L. Donnici, I.S. Moreira, P.C. Healy, S.J. Berners-Price, S.L. Queiroz, Polyhedron 20 (2001) 2123-2128.

[41] Enraf-Nonius, Collect, Nonius BV, Delft, The Netherlands (1997-2000).

[42] Z. Otwinowski, W. Minor, Macromolecular Crystallography, Part A, Academic Press, New York, 1997.

[43] P. Coppens, L. Leiserowitz, D. Rabinovich, Acta Crystallogr. 18 (1965) 1035-1038.

[44] M.A. Spackman, D. Jayatilaka, CrystEngComm 11 (2009) 19-32.

[45] J.J. McKinnon, M.A. Spackman, A.S. Mitchell, Acta Crystallogr. B 60 (2004) 627-668.

[46] M.A. Spackman, J.J. McKinnon, CrystEngComm (2002) 378-392.

[47] M.E. Reichmann, S.A. Rice, C.A. Thomas, P. Doty, J. Am. Chem. Soc. 76 (1954) 3047-3053.

[48] J.D. McGhee, P.H.V. Hippel, J. Mol. Biol. 86 (1974) 469-489.

[49] A. Wolfe, G.H. Shimer, T. Meehan, Biochemistry 26 (1987) 6392-6396.

[50] K.S. MacFarlane, A.M. Joshi, S.J. Rettig, B.R. James, Inorg. Chem. 35 (1996) 7304-7310.

[51] T.S. Lobana, P. Kaur, A. Castineiras, J. Coord. Chem. 58 (2005) 429-435.

[52] M.O. Santiago, A.A. Batista, M.P. de Araujo, C.L. Donnici, I.D. Moreira, E.E. Castellano, J. Ellena, S. dos Santos, S.L. Queiroz, Transit. Met. Chem. 30 (2005) 170-175.

[53] K. Wohnrath, A.A. Batista, A.G. Ferreira, J. Zukerman-Schpector, L.A.A. de Oliveira, E.E. Castellano, Polyhedron 17 (1998) 2013-2020.

[54] R.S. Correa, S.A. Santana, R. Salloum, R.M. Silva, A.C. Doriguetto, Acta Crystallogr. C 62 (2006) (0115-07).

[55] M. Cory, D.D. McKee, J. Kagan, D.W. Henry, J.A. Miller, J. Am. Chem. Soc. 107 (1985) 2528-2536.

[56] T.S. Kamatchi, N. Chitrapriya, H. Lee, C.F. Fronczek, F.R. Fronczek, K. Natarajan, Dalton Trans. 41 (2012) 2066-2077. 